COVER PHOTOGRAPHS

\begin{tabular}{|c|c|c|c|c|c|}
\hline 1 & 2 & 3 & 4 & \multirow{5}{*}{$\begin{array}{l}\text { 1. Asbestos ore } \\
\text { 2. Lead ore, Balmat mine, N. Y. } \\
\text { 3. Chromite-chromium ore, Washington } \\
\text { 4. Zinc ore, Friedensville, Pa. } \\
\text { 5. Banded iron-formation, Palmer, } \\
\text { Mich. } \\
\text { 6. Ribbon asbestos ore, Quebec, Canada } \\
\text { 7. Manganese ore, banded } \\
\text { rhodochrosite }\end{array}$} & \multirow{5}{*}{$\begin{array}{l}\text { 8. Aluminum ore, bauxite, Georgia } \\
\text { 9. Native copper ore, Keweenawan } \\
\text { Peninsula, Mich. } \\
\text { 10. Porphyry molybdenum ore, Colo } \\
\text { 11. Zinc ore, Edwards, N. Y. } \\
\text { 12. Manganese nodules, ocean floor } \\
\text { 13. Botryoidal fluorite ore. } \\
\text { Poncha Springs, Colo. } \\
\text { 14. Tungsten ore, North Carolina }\end{array}$} \\
\hline 5 & & 6 & & & \\
\hline & 7 & & 8 & & \\
\hline 9 & & 10 & & & \\
\hline 11 & 12 & 13 & 14 & & \\
\hline
\end{tabular}




\section{Computer-aided Estimates}

of Concentrating-grade Iron Resources

in the Negaunee Iron-formation,

Marquette District, Michigan

By W. F. CANNON, SANDRA L. POWERS, and NANCY A. WRIGHT

GEOLOGICAL SURVEY PROFESSIONAL PAPER 1045

An estimation of the magnitude, quality, and economic potential of subeconomic resources of iron

in an important active mining district

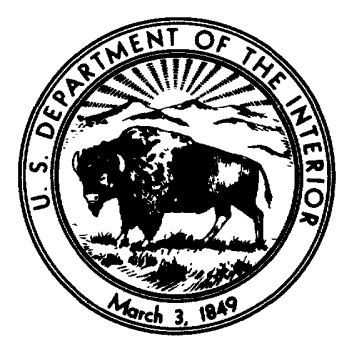

UNITED STATES GOVERNMENT PRINTING OFFICE, WASHINGTON : 1978 


\section{UNITED STATES DEPARTMENT OF THE INTERIOR}

CECIL D. ANDRUS, Secretary

GEOLOGICAL SURVEY

W. A. Radlinski, Acting Director

Library of Congress Cataloging in Publication Data

Cannon, W F

Computer-aided estimates of concentrating-grade iron resources in the Negaunee Iron-formation, Marquette District, Michigan.

(Geological Survey professional paper ; 1045)

Bibliography: p.

Supt. of Docs. no.: I 19.16:1045

1. Iron ores-Michigan-Marquette Co.-Data processing. I. Powers, Sandra L., joint author. II. Wright, Nancy A., joint author. III. Title. IV. Series: United States. Geological Survey.

Professional paper ; 1045.

TN403.M5C36 $\quad 553^{\prime} .4^{\prime} 0977496 \quad 77-608120$

For sale by the Superintendent of Documents, U.S. Government Printing Office

Washington, D.C. 20402

Stock Number 024-001-03059-4 


\section{CONTENTS}

Abstract

Introduction

Acknowledgments

Negaunee Iron-formation

Mineralogy and texture

Structural position and thickness

Resource data bank

Preparation of the data bank

Variables

Identification and location

Taconite characteristics

\begin{tabular}{r|}
\hline Page \\
1 \\
1 \\
2 \\
2 \\
2 \\
3 \\
3 \\
4 \\
5 \\
5 \\
7
\end{tabular}

Resource data bank-Continued

Variables-Continued

Deposit characteristics _._.

Reliability of data

Iron resources _. 9

Resource classification _.................... 11

Estimates of total recoverable iron 13

Future of taconite mining in the Marquette district.- 19

Effect of technologic advances on iron resources...- 20

Conclusions _............ 20

References cited
Page

\section{ILLUSTRATIONS}

FIGURE 1. Generalized geologic map of the Marquette district

Page

2

2. Hypothetical cross section of data block showing method by which variables are measured and assigned to blocks ........

3. Cumulative curve showing relationship between long tons of Negaunee Iron-formation and depth beneath the surface ....

4. Graph showing long tons of iron-formation in categories described in the text

5. Histogram showing long tons of the possibly treatable ironformation within 1,000 feet of the surface relative to volume of consolidated waste rock overlying it

6. Histogram showing long tons of the possibly treatable ironformation within 1,000 feet of the surface with various ratios of volume of iron-formation to volume of interlayered waste rock

7. Resource classification chart

8. Histograms showing results of three types of metallurgical tests

9. Geologic map of the Marquette district showing the distribution of various mineralogical classes of iron-formation within the Negaunee Iron-formation

10. Regression lines showing the negative correlation between concentrate-iron percentage and concentrate-silica percentage for three types of metallurgical tests

11. Curves showing maximum short tons of iron potentially available within 1,000 feet of the surface for two metallurgical classes of iron-formation at various cutoff grades

12. Graph showing projected production trends for the Marquette district from operating mines and announced expansion and development plans

9

10

11

11

12

14

16

18

18

19

\section{TABLES}

TABLE 1. Percentage of variation between original calculations and recalculated values of four variables for $1 / 4-\mathrm{mi}^{2}\left(0.65-\mathrm{km}^{2}\right)$ vertical columns through the iron-formation ..........................

2. Metallurgical data used in simulation model

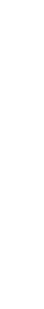





\title{
COMPUTER-AIDED ESTIMATES OF CONCENTRATING-GRADE IRON RESOURCES IN THE NEGAUNEE IRON-FORMATION, MARQUETTE DISTRICT, MICHIGAN
}

\author{
By W. F. Cannon, Sandra L. Powers, and Nancy A. Wright
}

\begin{abstract}
The Negaunee Iron-formation of Precambrian age is the principal iron-bearing unit in the Marquette iron range, Michigan. The Negaunee, along with other sedimentary and igneous rocks, is folded into a complex synclinal structure, the Marquette trough, and related smaller structures.

The Negaunee contains about 205 billion long tons of rock and averages 32 percent iron. By using a computerized data bank, we have analyzed the resource potential of the Negaunee, and by using a statistical simulation model, we have estimated the maximum amount of iron recoverable under present or moderately improved economic and technologic conditions.

Within the district is about 91.6 billion long tons of finegrained hematitic and goethitic iron-formation. About 28.4 billion long tons is within 1,000 feet $(304.8 \mathrm{~m})$ of the surface; this material could yield a maximum of about 7 billion short tons of iron in concentrates that contain 60-65 weight-percent iron. The concentrates could be produced by selective flocculation and flotation, or some modification of that process, such that recovery of iron is at least 20 weightpercent of the crude ore.

Magnetic iron-formation constitutes about 48 billion long tons. About 10.5 billion long tons is within 1,000 feet ( 304.8 $\mathrm{m}$ ) of the surface and could yield a maximum of about 3 billion short tons of iron in concentrates produced by magnetic separation. The recovery of iron is at least 20 weightpercent of the crude ore.

In addition, about 27.1 billion long tons of iron-formation contains coarse-grained hematite. About 4.8 billion long tons is within 1,000 feet $(304.8 \mathrm{~m})$ of the surface and could yield a maximum of about 0.7 billion short tons of iron in concentrates produced by froth flotation; the iron recovered is at least 20 weight-percent of the crude ore.

Silicate iron-formation constitutes about 37.6 billion long tons, about 5.6 billion long tons of which is within 1,000 feet $(304.8 \mathrm{~m})$ of the surface. However, the silicate ironformation is not amenable to concentration by present technology.
\end{abstract}

\section{INTRODUCTION}

The Marquette iron range was the first of the great Lake Superior iron-ore districts to be discovered. The iron resources of the district are in the Negaunee Iron-formation, a sedimentary accumulation of iron minerals. Shortly after the discovery of the Negaunee in 1844, iron production began, and since that time, the district has been one of the principal sources of iron ore for the United States. Most ore mined before the 1950's was from high-grade deposits that formed as secondary concentrations in the Negaunee Iron-formation. In the 1950's, when reserves of high-grade ore were being depleted rapidly, the technology for processing lower grade ore was developed, and since that time production from the Marquette range has come increasingly from concentrating-grade ore, commonly called taconite.

The technology for producing a merchantable iron-ore product from taconite is complex and, in general, involves open-pit mining, multistage crushing and grinding, a process for separating iron minerals from gangue minerals, and an agglomerating process (most commonly, pelletizing) for the ironmineral concentrate. The economic availability of iron from a taconite deposit is determined by many factors, only some of which are geologic. Hence, by using only geologic data as is done in this study, we are not able to estimate reserves ${ }^{1}$ of taconite. Rather, in this paper, we intend to present estimates for the Marquette District of the maximum amount of iron that is geologically known as well as the amount that is potentially recoverable. The estimates are derived by using data from a detailed data bank developed for that purpose.

In this paper, iron resources are classified according to the degree to which they approach the geologic characteristics of presently economic deposits and the degree of certainty with which the deposit is known. Mathematical simulation models are used to derive maximum estimates of recoverable iron

1 A reserve is considered to be material from which iron can be economically and legally extracted at the present time. This study is concerned with resources, which are considered to be material from which extraction of iron is currently or potentially feasible. Resources there fore include reserves, but also include much more material whose recovery may or may not be economically feasible. 
from material that is geologically most similar to presently economic deposits. Finally, the degree to which future technologic advances in several fields would affect the resource base of the district is discussed.

\section{ACKNOWLEDGMENTS}

The data that have made this report possible were collected during many years of field and laboratory work by U.S. Geological Survey personnel. We wish to thank J. E. Gair, W. P. Puffett, G. C. Simmons, L. D. Clark, and J. S. Klasner, who, along with the senior author, have participated in studies of the Marquette district, and who have made available to us much original information and material. We are also greatly indebted to the mining companies in the area who, for many years, have been very cooperative in supplying information from diamond drilling and mining operations. This information has included subsurface data that have permitted an accurate three-dimensional analysis of the district.

Lawrence J. Drew of the U.S. Geological Survey designed and wrote a computer program used for Monte Carlo simulation of iron resources.

\section{NEGAUNEE IRON-FORMATION}

The Negaunee Iron-formation, the principal iron resource of the Marquette range, is a stratigraphic unit in the complexly folded and faulted Marquette trough and adjacent smaller structures-the Palmer basin, Republic trough, and Mitchigan River trough (see fig. 1). All the structures are synclines complicated by faulting. The iron-formation is part of the Marquette Range Supergroup, a thick accumulation of sedimentary and volcanic material about 2 billion years old.

The mineralogy, texture, and structural position of the Negaunee vary greatly within the district and have been mapped and described by Simmons (1974), Puffett (1974), Cannon (1974), Gair (1975), Clark, Cannon, and Klasner (1975), Cannon (1975), Cannon and Klasner (1974, 1975a, b), and Klasner and Cannon (1975a, b). The generalized description that follows is based on those more detailed descriptions.

\section{MINERALOGY AND TEXTURE}

The sediments of the Negaunee Iron-formation were deposited as very fine grained chemical precipi-

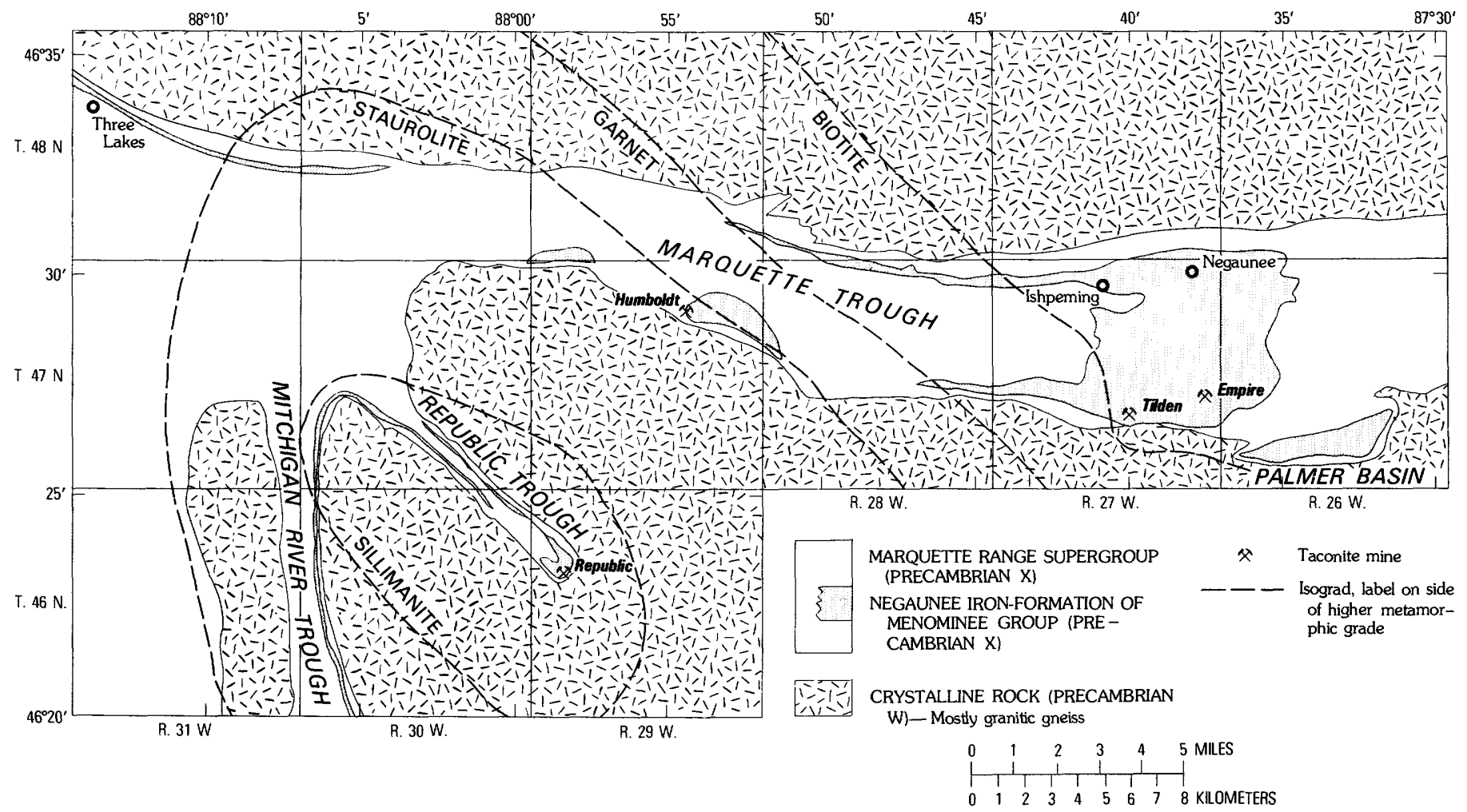

FIGURE 1.-Generalized geologic map of the Marquette district showing the distribution of the Negaunee Iron-formation and the location of metamorphic isograds (modified from James, 1955). 
tates in which siderite, iron-silicate minerals, and iron oxides and hydroxides accumulated to form iron-rich layers, commonly interbedded with siliceous (cherty) layers. The mineralogy differed from place to place, probably as a result of varying physical and chemical environments during or shortly after deposition (James, 1954). The mineralogy was further affected by diagenesis, regional metamorphism, and weathering.

Metamorphism has had a very profound effect on the mineralogy of the Negaunee, commonly resulting in nearly total change in the original mineralogical makeup. Metamorphic isograds mapped by James (1955) and slightly modified by subsequent work are shown in figure 1 . In the east end of the Marquette district, the Negaunee is least metamorphosed, and iron-bearing minerals are chiefly siderite, minnesotaite, stilpnomelane, magnetite, hematite, and goethite. Grain size is very small, generally less than 0.002 inch $(0.05 \mathrm{~mm})$. As metamorphic grade increased, siderite and minnesotaite were converted to other minerals, chiefly grunerite, within the biotite zone, and grain size became progressively larger. At metamorphic grades higher than those in the biotite zone, no significant mineralogic changes occurred. Grunerite, magnetite, and hematite remained stable and are the principal iron-bearing minerals in rocks of the highest grade attained (sillimanite zone). Chert grain size is as large as 0.02 inch $(0.5 \mathrm{~mm})$ in rocks of the highest metamorphic grades, and some iron minerals are several times larger. In general, the banded cherty nature of the rock is preserved to the highest metamorphic grades. In the area shown in figure 1, west of the garnet isograd, the relatively coarse grain size has inhibited secondary oxidation, and oxidative weathering has not been an important mineral-forming process; east of the garnet isograd much of the iron-formation has been deeply weathered, and all the goethite and part of the hematite were formed by postmetamorphic weathering of siderite, minnesotaite, and magnetite.

\section{STRUCTURAL POSITION AND THICKNESS}

The Negaunee Iron-formation is folded into a doubly plunging synclinorium in the Marquette trough (see fig. 1). The iron-formation attains its greatest thickness $(3,300-3,900 \mathrm{ft} ; \sim 1,000-1,200$ $\mathrm{m})$ near the west-plunging keel of the synclinorium a few miles south of the towns of Negaunee and Ishpeming. Because of limited erosion of the syncline and the relatively gentle plunge $\left(20^{\circ}-30^{\circ}\right)$ and great stratigraphic thickness of the folded unit, a very large area is underlain by the iron-formation. The synclinorium generally maintains a westward plunge from its eastern end to the vicinity of Humboldt, where the deepest parts of the formation are believed to be about 8,200 feet $(2,500 \mathrm{~m})$ below the surface (Klasner and Cannon, 1974). The formation thins abruptly away from the exposed keel, also thins along the buried keel, and commonly has a thickness of $250-500$ feet $(\sim 80-160 \mathrm{~m})$ where exposed along the steeply dipping limbs. In much of western Marquette district, the Negaunee is absent as a result of truncation along an overlying unconformity. The westernmost occurrence of the Negaunee is along the north limb of the synclinorium near the community of Three Lakes.

In the Palmer basin (see fig. 1), the Negaunee is about 1,100 feet $(\sim 350 \mathrm{~m})$ thick and is folded into a half syncline consisting of a south limb and keel; the north limb has been eliminated by faulting. The structure is as much as 2,500 feet $(\sim 750 \mathrm{~m})$ deep. The Mitchigan River trough is likewise a half syncline because the west limb has been eliminated by faulting. The Negaunee there can be as much as 1,000 feet $(\sim 300 \mathrm{~m})$ thick, and the trough is about 6,500 feet $(\sim 2,000 \mathrm{~m})$ deep

The Republic trough is a syncline that plunges about $45^{\circ} \mathrm{NW}$. at the exposed keel but is believed to decrease in plunge toward the northwest. In this trough, the Negaunee is generally thin, in several areas is absent, and only near the exposed keel reaches a significant thickness of as much as 1,000 feet $(\sim 300 \mathrm{~m})$

\section{RESOURCE DATA BANK}

Between 1957 and 1974, the U.S. Geological Survey mapped the Marquette district, including the Negaunee Iron-formation, in detail. During that work, a vast amount of petrologic and structural information was accumulated, and, with the cooperation of the mining companies active in the area, a file of diamond-drilling records was compiled. In 1975 , we began a project to organize that information into a computerized data file on iron resources.

The basic element of the data system consists of blocks measuring $1 / 2 \times 1 / 2$ mile $(0.8 \times 0.8 \mathrm{~km})$ horizontally and 500 or 1,000 feet (152.4 or $304.8 \mathrm{~m}$ ) vertically. Thus, the area of the district underlain by iron-formation was divided into $1 / 4-\mathrm{mi}^{2}\left(0.65-\mathrm{km}^{2}\right)$ areas and divided into horizontal slabs from the surface to $-\mathbf{5 0 0}$ feet $(-\mathbf{1 5 2 . 4} \mathrm{m}),-\mathbf{5 0 0}$ feet to $-1,000$ feet $(-152.4 \mathrm{~m}$ to $-304.8 \mathrm{~m})$ and then into deeper 1,000-foot- (304.8-m-) thick slabs to the base of the iron-formation. For each three-dimensional block thus defined, about 45 variables were measured, 
calculated, or estimated. All variables were entered into a computerized file; by means of the Geologic Retrieval and Synopsis Program, GRASP (Bowen and Botbol, 1975), the data can be classified and recalled by any of the variables or any combination of variables.

The data bank can be used as an information system that will answer any question that can be phrased in terms of listed variables, as long as the questioner considers the limitations imposed by the manner in which values were determined and stored.

\section{PREPARATION OF THE DATA BANK}

For this resource evaluation, we needed to prepare, as quickly as possible, a computer file of information about the blocks within the Marquette district. In order to determine what variables would be included in the file and hence, how the data-input form would be designed, we needed to consider first what questions would be asked of the final data system. Once this was established, a simple input form was designed to record the data as efficiently and easily as possible.

The next task was to make the data machinereadable. The conventional method is to use punch cards, but because of the large volume of data involved in this project, cassette tapes were used to record the data. The tapes are small, hold a relatively large amount of data, and are reusable once the data contained on them have been transmitted to the computer.

A problem in making the data machine-readable is the introduction of errors. Each time data are translated from one medium to another, errors may be introduced. For this project, a programmable data-entry station was used, not only because it generates cassette tapes, but also because it can do a limited amount of data editing. The data-entry station is much like a keypunch machire in concept. As data are typed at a keyboard, they appear on a CRT (cathode ray tube) screen. After a certain amount of data accumulates on the screen, it can be edited, corrected if necessary, and then transferred electronically from the screen to the cassette tape, thus clearing the screen for more data. For ease of entry and editing, a preprogrammed "form" appears on the screen; the "form" nas a format similar to the sheet on which data are originally recorded. Certain errors are automatically detected. For instance, a nonnumeric character cannot be entered in a numeric-only field, and vice-versa. If a mistake is made, an alarm sounds, and the operator must make the correct entry before the machine will continue.
In addition, the data-entry station is programmable to the extent that it can generate new numbers for a given record on the basis of numbers already entered. Using available arithmetic operators, it is possible to generate ratios, sums, products, and so on, in various combinations and to incorporate the resultant number as part of the record. For this discussion, a record is one block in the Marquette district and all the data associated with that block. Each record is written on the cassette tape in fixed format, meaning that in each record, items always appear in the same position and have the same number of characters.

After the data are in machine-readable form, they are transmitted to the computer for processing. The data-entry station is used for this job also. Because the data-entry station is programmable it can be made to appear to the host computer as a teletype terminal. The data can then be transmitted to the computer through the use of a voice-grade telephone connected to the terminal through an' acoustic coupler.

Because the final data file needs to be accessible in an interactive mode, the host computer has to be a timesharing computer. The computer of a private company whose function is to sell computer time was deemed the most appropriate, both in cost and in speed of processing.

The software system chosen to manage the data is known as the Geologic Retrieval and Synopsis Program (GRASP) (Bowen and Botbol, 1975). GRASP is a set of Fortran IV subroutines and a main driver that provides interactive access to geologic data. Because GRASP is a machine-independent interactive system, it was available on the chosen computer.

The Marquette district GRASP file actually consists of four files: mask file, definitions file, dictionary file, and numeric master file. The mask file contains a short acronym for each of the 45 variables abundant iron mineral or formation name, the mask file tells the GRASP system whether a particular field will contain a real (decimal) number, an integer (whole) number, or character-string (alphanumeric). For character-string items, such as most abundant iron mineral or formation name the mask file also has a numeric pointer to the first entry in the dictionary file associated with that item. The dictionary file is a list of all the possible characterstring items that could appear in the GRASP file. At present it has 73 entries. All the items for each field are grouped together in the dictionary file, which contains a count of how many items there are 
for each field. The definition file's main purpose is to provide a full breakdown of the 45 variables into various categories of information in the GRASP file (such as, taconite characteristics, deposit characteristics), as well as to provide a description of each acronym. The numeric master file is the actual data file, but it is far different in appearance from the raw data as they initially appear on the time-sharing computer. Each of the alphanumeric entries has been replaced by a number indicating that entry's relative position in the dictionary file. An important point is that the use of this method of storing dictionary pointers rather than the long characterstring entry saves a considerable amount of space in the computer. For instance, instead of having the full county name "Marquette" appear in every record in that county, the word is replaced by a number indicating its position in the dictionary. Decimal number and integer data fields are stored as they were entered. For a given record, several fields may have been left blank on the original input sheet, meaning that the data for a particular item are unavailable. The GRASP software will compress the data so that the numeric master file is as small as possible.

A Fortran IV program, BUILD1, changes the raw input record into the compressed unformatted binary numeric master file. The BUILD1 program reads in each transmitted record, checks for blank numeric fields to ensure that they do not get stored as zero, compares each alphanumeric entry in each raw-data record with the contents of the appropriate part of the dictionary file in order to determine that entry's numeric position in the dictionary, and finally writes the transformed record into the numeric master file. The program is run once for each cassette file that is transmitted to the timesharing computer. BUILD1 has been designed so that records that are already a part of the numeric master file may be updated easily. The update part of the program applies to numeric fields only. The resultant new numeric master file will then contain the old numeric master file and any updates that have been made, as well as the most recently transmitted cassette file. In addition to the electronic editing performed during the initial data entry and the editing functions of the programs, the entire data set was edited manually by comparing printouts of the data with the original data sheets.

At this point the file can be interrogated by the GRASP system. Among the things GRASP can be used for is the creation of subfiles. Through use of condition, logic, and search commands, these sub- files can be generated according to user-specified criteria. The following are examples of subfiles: (1) all the blocks whose most abundant iron mineral is magnetite and which contain 15 million to 30 million tons of iron ore, and (2) all the blocks that have a grain size of less than 0.02 inch $(0.5 \mathrm{~mm})$ or a maximum Pleistocene thickness of no more than 120 feet $(37 \mathrm{~m})$. Simple statistical operations can be performed on the master file or any subfiles. By use of the function command, the user can obtain the maximum, minimum, mean, variance, and standarddeviation values for any of the variables. Not only are they important numbers in themselves, but the maximum and minimum values are quite valuable as secondary editing numbers. Extremely high or low numbers will show up as errors and can be flagged and changed. The program will also calculate the slope, intercept, and correlation coefficient for a least-squares regression line between any two numeric variables.

The final data file contains 1,860 records which are all accessible and updatable by the GRASP software system. On the basis of any given set of conditions and associated logic, it takes about 45 seconds to search the entire file and to select the appropriate records to be stored in a subfile. The total cost of this operation averages about $\$ 2.75$ for each computer run.

\section{VARIABLES}

Each of 1,860 blocks containing iron-formation is characterized by a set of variables described below. A hypothetical cross section and data block are shown in figure 2 to illustrate the manner in which certain variables were measured and assigned to blocks.

\section{IDENTIFICATION AND LOCATION}

These variables provide information on the identification and geographic and spatial location of individual blocks.

Unique identification number.-The district was divided on a half-mile $(0.8-\mathrm{km})$ grid by north-south and east-west lines, and each $1 / 4-\mathrm{mi}^{2}\left(0.65-\mathrm{km}^{2}\right)$ area was assigned a unique identifying number, ID1, that corresponds to a number assigned to that block on an index map of the district. The district was further divided into horizontal slabs, either 500 feet $(152.4 \mathrm{~m}$ ) thick (for the two slabs nearest the surface) or 1,000 feet $(304.8 \mathrm{~m})$ thick. The depth below the surface is indicated by ID3, the depth to the bottom of the slab. These two are separated by ID2, an alpha character coded to indicate the formation 


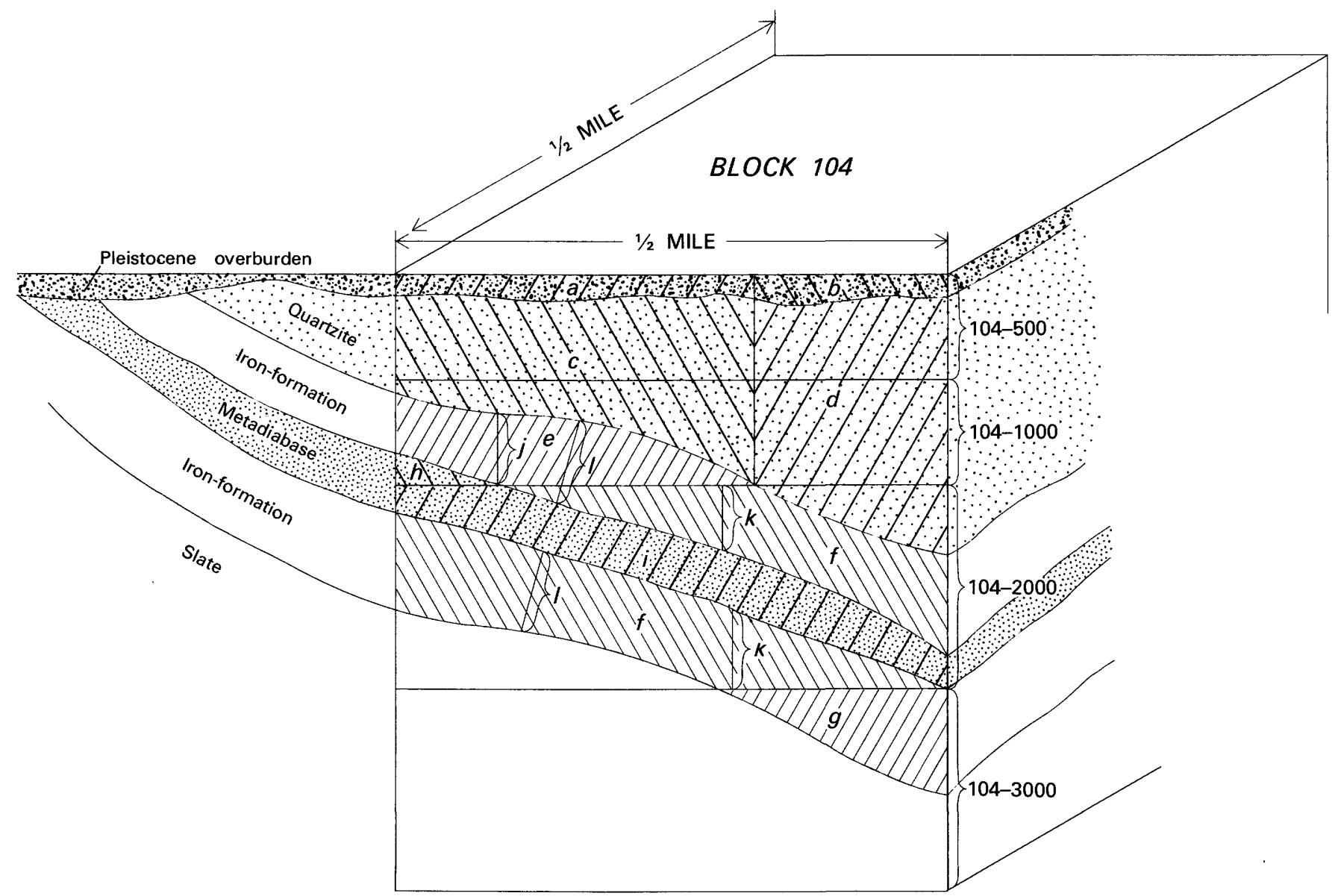

a-Unconsolidated stripping required to uncover iron-formation in block 104-1000

$b$-Unconsolidated stripping required to uncover iron-formation in block 104-2000

$c$ - Consolidated stripping required to uncover iron-formation in block 104-1000

$d$-Consolidated stripping required to uncover iron-formation in block 104-2000

$e$-Iron-formation in block 104-1000

$f$-Iron-formation in block 104-2000

$g$-Iron-formation in block 104-3000

$h$-Interlayered waste in block 104-1000

i Interlayered waste in block 104-2000

j- Iron-formation thickness for block 104-1000

$k$ - Iron-formation thickness for block 104-2000

1- Formation thickness for blocks 104-1000, 2000, and 3,000

FigURE 2.-Hypothetical cross section of data block showing method by which variables are measured and assigned to blocks. No entry is made for block $104-500$ because it contains no iron-formation. No stripping is assigned to block 104-3000 because all overlying waste would be removed in mining blocks 104-1000 and 104-2000.

or member to which the data apply. Thus, a complete identification number, for instance, "104A2000," identifies material in the $1 / 4-\mathrm{mi}^{2}\left(0.65-\mathrm{km}^{2}\right)$ area numbered " 104 " on index sheets, and in the slab $1,000-2,000$ feet $(304.8-609.6 \mathrm{~m})$ beneath the surface, and the information pertains to a stratigraphic unit "A," a code for the stratigraphic name of the unit.
UTM coordinates.-The Universal Transverse Mercator grid (UTM) was used to locate each block more definitely. The UTM northing and UTM easting for the southeast corner of each block are two additional identification and location variables. They were measured from $71 / 2$-minute topographic maps.

County.-The county variable identifies the county in which the block is found. 
TACONITE CHARACTERISTICS

Seventeen variables are included that give information on the nature and magnitude of iron-formation within a block.

Grade.-Five variables give the percentage of iron, silica, phosphorous, manganese, and alumina in the iron-formation. Values were obtained mostly from assays of drill core provided by mining companies but also from analyses by the U.S. Geological Survey of drill core and samples from outcrops. Because much of the drilling was done in exploration for high-grade ore, many cores are partly in material that has undergone secondary enrichment, and thus, the cores are not representative of most of the iron-formation. To avoid biasing our values by these higher grade cores, any analyses of greater than 40 percent iron were excluded from our data.

Volume of iron-formation.-The volume of ironformation in millions of cubic feet contained in each slab is calculated from cross sections drawn at $1 / 2-\mathrm{mi}$ $(0.8-\mathrm{km})$ intervals approximately perpendicular to the strike of the iron-formation. Where the shape of the iron-formation between cross sections is too irregular to approximate by considering only end areas, the volume is estimated by approximating the shape by means of combinations of polyhedral forms whose volume can be calculated from simple formulas.

Density of iron-formation.-The density of ironformation is recorded in short tons per cubic foot. It is determined individually for each slab from a graph relating density to iron percentage.

Millions of short tons of iron-formation.-The amount of iron-formation in millions of short tons is determined by multiplying density by the volume of iron-formation in the block.

Millions of short tons of iron.-The amount of iron in millions of short tons is determined by multiplying millions of short tons of iron-formation in the block by the iron percentage.

Grain size.-The grain-size variable indicates the size, in millimeters, of chert grains. The value is determined either by direct measurement in thin sections or is derived from the location of the block with respect to metamorphic isograds by using observed relationships between metamorphic grade and grain size.

Most abundant iron mineral.- The most abundant iron-bearing mineral within the entire slab is determined. It may represent an average determined from two or more lithologic types of iron-formation. Mineralogic content is determined from drill records, thin sections, and field observations.
Other iron minerals.-Three variables indicate other abundant (more than 10 percent) iron minerals contained in the slab.

Accessory minerals.-The three most common accessory minerals (less than 10 percent), excluding quartz, are listed as separate variables.

\section{DEPOSIT CHARACTERISTICS}

The remaining variables describe mostly geometric and geologic relationships of the deposit and can be used to judge its minability.

Formation name.-The stratigraphic name of the formation or member is included here and is an alternative means of storing and retrieving the information given by ID2, but here is listed in full in alpha characters rather than in coded form.

Formation thickness.-The total stratigraphic thickness of the iron-formation of which the material included in the block is a part ( $l$ in fig. 2$)$ is indicated.

Iron-formation thickness.-The maximum vertical thickness of iron-formation within the block ( $j$ and $k$ in fig. 2) is defined.

Interlayered waste thickness.-The thickness of waste rock, determined largely from drill data, is listed.

Iron-formation/waste.-Iron-formation/waste is calculated as the ratio of thickness of iron-formation to thickness of waste rock.

Dip.- The average dip of bedding of the ironformation estimated to the nearest $5^{\circ}$ is listed here.

Thickness of Pleistocene overburden.-The thickness of Pleistocene cover is measured in feet and includes separate variables for maximum, minimum, and average thickness. Values are determined from diamond-drilling and water-well records.

Stripping required to uncover iron-formation.Separate values are given for consolidated ( $c$ and $d$ in fig. 2) and unconsolidated ( $a$ and $b$ in fig. 2) stripping. Unconsolidated stripping is calculated by using the average Pleistocene thickness. Consolidated stripping is calculated from the same cross sections used to calculate iron-formation volume. Only material within the block is considered, so that figures do not reflect the total amount of rock that might have to be moved to actually mine the iron-formation because mining might also require moving rock in adjacent blocks.

Interlayered waste-rock type.-Two variables identify the two most common types of rock interlayered with the iron-formation. They are determined largely from drill records. 
Overlying waste-rock type.-Two variables identify the two most common rock types that form overlying waste rock.

Magnitude of deposit.-The total size of the deposit of which the material in the block forms a part is identified. Individual deposits are defined primarily by mineralogy, grain size, depth, and waste ratios.

Amount of previous mining.-A coded alpha character is used to identify small open-pit mines, large open-pit mines, small underground mines, large underground mines, and no mines. One million long tons of ore shipped is used as the dividing line between large and small mines.

Number of data points.- The total number of points in the slab at which some information about the iron-formation is known is indicated. Points include outcrops, drillholes, and mine workings.

Number of drillholes.-The number of drillholes that penetrate the slab are indicated.

Million short tons of iron-formation under water. -The amount of iron-formation directly beneath lakes or major streams is indicated.

\section{RELIABILITY OF DATA}

Data from about 1,600 outcrops and 3,300 drillholes were used to draw cross sections and to calculate values of the variables. The data density varies considerably both areally and with depth, and the reliability of values likewise varies considerably. To test the reproducibility of our figures, an area near Ishpeming that has about average data density was chosen for recalculation. The ability to reproduce values such as those of chemical composition, grain size, and mineral content is good because these are derived in a methodical manner from available data. Barring mechanical errors in calculation or in transscribing data, reproducibility of such data approaches 100 percent. For calculation of other important variables, including volume of iron-formation, thickness of iron-formation, volume of interlayered waste rock, and volume of consolidated rock required to be stripped, the ability to reproduce values is almost entirely a function of ability to. reproduce cross sections. To test this ability we redrew sections from outcrop and drilling data and recalculated these values for 39 blocks in nine $1 / 4-$ - $^{2}$ $\left(0.65-\mathrm{km}^{2}\right)$ areas to a maximum depth of 5,000 feet $(1,524 \mathrm{~m})$ below the surface. Comparing these with our original calculations, we found that figures for individual blocks commonly agreed within 20 percent but that much greater differences were also common. Large discrepancies are mostly due to differences in the placement of contacts between iron-
TABLE 1.-Percentage of variation between original calculations and recalculated value of four variables for $1 / 4-m i^{2}$ $\left(0.65-\mathrm{km}^{2}\right)$ vertical columns through the iron-formation

[Positive variations indicate cases in which recalculated values exceeded original values. Negative variations indicate cases in which recalculated values were less than original values!

\begin{tabular}{|c|c|c|c|c|c|c|c|c|}
\hline \multirow[b]{2}{*}{ Block } & \multicolumn{2}{|c|}{$\begin{array}{c}\text { Volume } \\
\text { taconita } \\
\left(\mathrm{ft}^{3} \times 10^{6}\right)\end{array}$} & \multicolumn{2}{|c|}{$\begin{array}{c}\text { Taconite } \\
\text { thickness } \\
\text { (ft) }\end{array}$} & \multicolumn{2}{|c|}{$\begin{array}{c}\text { Waste } \\
\text { thickness } \\
(\mathrm{ft})\end{array}$} & \multicolumn{2}{|c|}{$\begin{array}{c}\text { Consolidated } \\
\text { stripping } \\
\left(\mathrm{ft}^{3} \times 10^{6}\right) \\
\end{array}$} \\
\hline & $\frac{\varpi}{\mathscr{E}}$ & 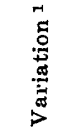 & 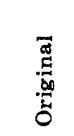 & 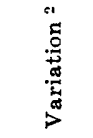 & . & م & 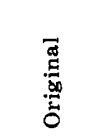 & 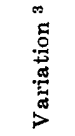 \\
\hline $\begin{array}{r}127 \\
115 \\
103 \\
91\end{array}$ & $\begin{array}{r}14,519 \\
12,895 \\
16,190 \\
14,797 \\
4,235\end{array}$ & $\begin{array}{r}-15 \\
-14 \\
+2 \\
+7 \\
-1\end{array}$ & $\begin{array}{l}3,357 \\
2,380 \\
2,757 \\
2,988 \\
2,183\end{array}$ & $\begin{array}{l}+0.2 \\
-10 \\
+5 \\
+5 \\
+.2\end{array}$ & $\begin{array}{r}943 \\
920 \\
1,243 \\
1,012 \\
467\end{array}$ & $\begin{array}{l}-7 \\
-8 \\
-5 \\
-5 \\
+5\end{array}$ & $\begin{array}{l}4,437 \\
3,147 \\
2,163 \\
1,816 \\
\text { no stri }\end{array}$ & $\begin{array}{c}+3 \\
+8 \\
+2 \\
+4 \\
\text { pping }\end{array}$ \\
\hline $\begin{array}{l}139 \\
151 \\
163 \\
175 \\
175\end{array}$ & $\begin{array}{r}10,696 \\
10,598 \\
9,223 \\
633\end{array}$ & $\begin{array}{r}-2 \\
+1 \\
-28 \\
+5 \\
\end{array}$ & $\begin{array}{l}1,938 \\
1,912 \\
1,799 \\
1,188\end{array}$ & $\begin{array}{r}-11.6 \\
-4.9 \\
+12.7 \\
+45.1 \\
\end{array}$ & $\begin{array}{r}1,062 \\
437 \\
201 \\
12\end{array}$ & $\begin{array}{r}-1 \\
-3 \\
-13 \\
-17 \\
\end{array}$ & $\begin{array}{c}\text { no stri } \\
56 \\
\text { no.stri } \\
\text { no stri }\end{array}$ & $\begin{array}{c}\text { pping } \\
+0.2 \\
\text { pping } \\
\text { pping } \\
\end{array}$ \\
\hline Average & ...... & -5 & & +4.6 & & -6 & & +2.6 \\
\hline
\end{tabular}

1 Percentage of variation of recelculation from original normalized against total volume of block.

2 Percentage of variation of recalculation from original normalized against total thickness of block.

${ }^{3}$ Percentage of variation of recalculation from original normalized against volume of block to the maximum depth of consolidated stripping.

formation and interlayered metadiabase sills. Commonly such discrepancies are self-cancelling when several adjacent blocks are considered together. For instance, a different interpretation of the position of a unit of waste rock might decrease the calculated volume of iron-formation for one block but would increase it by a corresponding amount for an adjacent block. If an entire $1 / 4-\mathrm{mi}^{2}\left(0.65-\mathrm{km}^{2}\right)$ vertical column through the iron-formation is considered, as in table 1 , the variation is generally small, especially when normalized against the total volume of the block. The average of these variations is well within 10 percent error for all variables considered. If a still larger area were considered, the variation would probably be even smaller. In light of these figures, we feel that our values for individual blocks should be reproducible to within 20 percent about 60 percent of the time, but total figures for five or more adjacent blocks are reproducible to within 20 percent about 70 percent of the time, and to within 10 percent about half the time. Considering the variation normalized against the total volume of rock being considered, the observed variation is less than 10 percent of the total volume about 80 percent of the time. Thus, values that are derived simply by arithmetic manipulation of data are considered to be essentially 100 percent reproducible. Other values, derived by calculations from cross sections, are considered to have, on the average, an error of less than 10 percent of the volume of rock within the area of calculation. 
The figures used throughout this report for tons ${ }^{2}$ of iron-formation should be considered maximum figures. In calculating the values for tons of ironformation, we calculated a total volume of ironformation and interlayered waste, and then we subtracted the tonnage of identified waste. In many areas probably not all waste rock was encountered in outcrop or diamond drilling, so our values for iron-formation, on the average, may be somewhat larger than the actual tonnage. Also, because considerable variation, on a scale too small to differentiate with our data, may exist in the iron-formation within a single block, the total calculated tonnage may be greater than the tonnage that could be processed successfully by any single concentrating technique. At taconite mines, changes in mineralogy or texture, some very subtle, render processing of parts of the iron-formation uneconomic. No attempt was made to exclude any type of iron-formation from our calculated values of tons of iron-formation in each block, hence, the tonnage of economically available ironformation in many blocks is probably smaller than our calculated values.

\section{IRON RESOURCES}

The Negaunee Iron-formation contains a total of about 205 billion tons of material in the Marquette district. The average iron content ${ }^{3}$ is 32 percent, and the average for 95 percent of individual blocks ranges from 27.5 to 36.5 percent. In order to avoid an arbitrary cutoff of resource figures, the entire Negaunee is considered a resource even though a substantial part of the iron is far from economically recoverable at present.

The economic potential of iron-formation is determined largely by the types of processes by which iron can be concentrated. At present, iron can be recovered only from oxide and hydroxide minerals. Three different processes are in use in the district. Where iron is largely in magnetite, a magnetic separation is used. Where coarse-grained (>0.002 in.; $0.05 \mathrm{~mm}$ ) hematite is predominant, it is concentrated by froth flotation, and where fine-grained oxides and hydroxides predominate, they are concentrated by a complex flocculation and flotation process. The potential of iron-formation as mill feed for any of these processes is determined largely by mineralogy and grain size rather than by iron content. Total iron is not a variable of primary importance because almost all the iron-formation contains more

\footnotetext{
2 Unless otherwise specified, figures are in long tons-2,240 lb. A long ton is about 1.02 metric tons.

" Percent iron is acid-soluble iron, that is, iron in oxide, hydroxide or carbonate minerals, except for silicate-rich iron-formation in which percent iron is total iron determined by complete chemical analysis.
}

than 27 percent iron. Iron in silicate or carbonate minerals cannot be recovered so that total iron is commonly substantially greater than recoverable iron. Thus, mineralogy and grain size are two of the most important variables on which we have based our resource classification.

Under present conditions, underground mining of taconite is not profitable; thus all taconite mines now are open pits. Therefore, depth below the surface is also an important variable for resource classification. Figure 3 shows the relationship between tons of iron-formation and depth. We have chosen 1,000 feet $(304.8 \mathrm{~m})$ as the average maximum depth of iron-formation that is accessible from open pits. In some areas, deeper pits are possible. For instance, the Empire pit (see fig. 1) may ultimately reach a depth of 1,600 feet $(487.7 \mathrm{~m})$, but such deep pits require exceptionally favorable conditions. Figure 3 shows that about 49 billion long tons or about onequarter of the iron-formation is within 1,000 feet $(304.8 \mathrm{~m})$ of the surface.

Figure 4 shows the iron-formation classified by mineralogy. Fine-grained hematite and goethite iron-formation, part of which can be concentrated by selective flocculation and flotation, constitutes the largest mineralogic class, totalling about 91.6 billion long tons. About 28.4 billion long tons of this

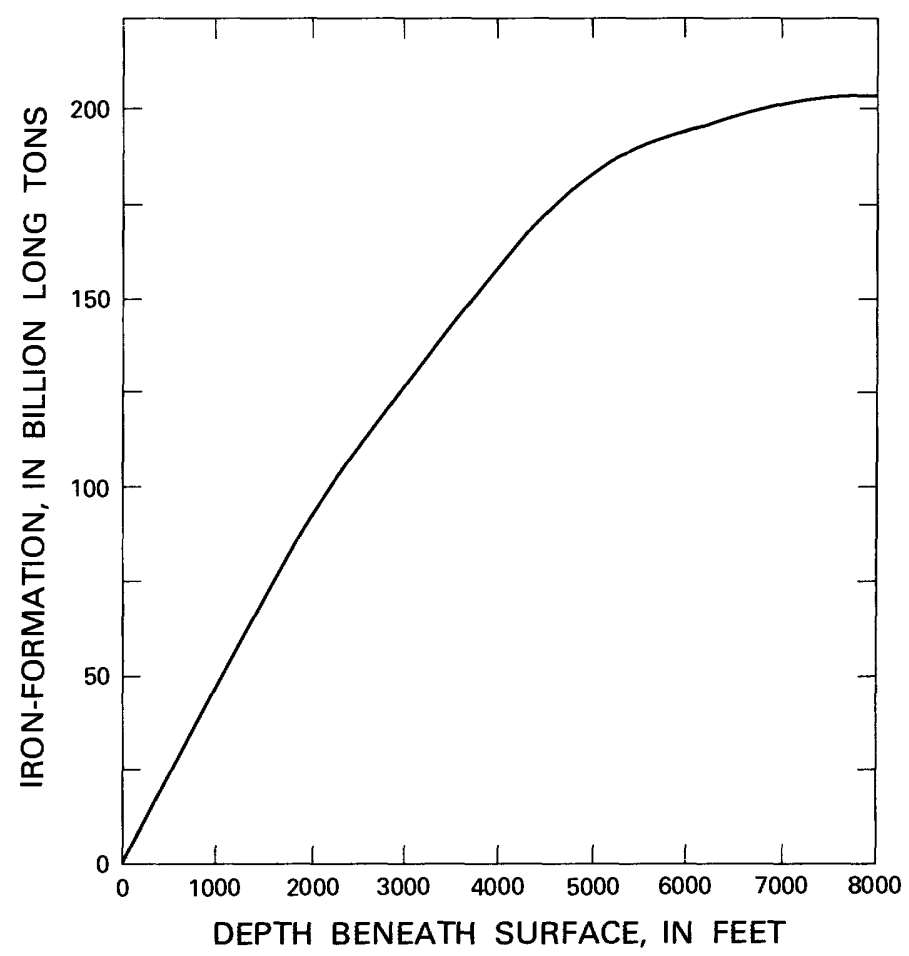

Figure 3.-Cumulative curve showing relationship between billions of long tons of Negaunee Iron-formation and depth beneath the surface. 


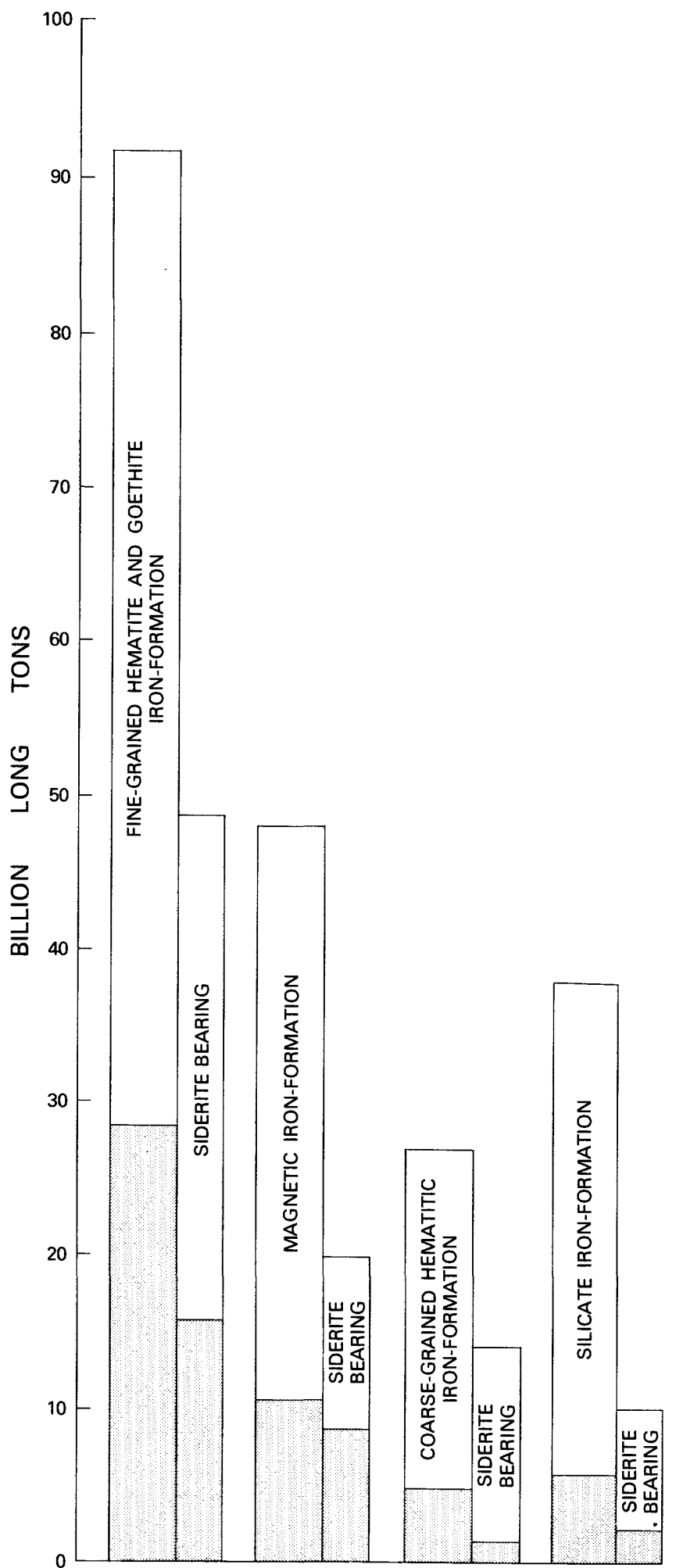

FiguRe 4.-Graph showing billions of long tons of Negaunee Iron-formation in categories described in the text. Shaded part of bars is iron-formation within 1,000 feet $(304.8 \mathrm{~m})$ of the surface. Smaller bars indicate amount of each class that contains more than 10 percent siderite. material is within 1,000 feet $(304.8 \mathrm{~m})$ of the surface. Next in importance is iron-formation containing magnetite as the most abundant mineral. About 48 billion long tons of this type is present, of which about 10.5 billion long tons is within 1,000 feet $(304.8 \mathrm{~m})$ of the surface. Coarse-grained hematitic iron-formation, concentratable by froth flotation, is the least abundant type, totalling about 27.1 billion long tons, of which only about 4.8 billion long tons is within 1,000 feet $(304.8 \mathrm{~m})$ of the surface. Silicate iron-formation, not amenable to concentration by means of present technology, totals about 37.6 billion long tons, about 5.6 billion long tons of which is within 1,000 feet $(304.8 \mathrm{~m})$ of the surface. About 92.5 billion long tons of the iron-formation is also siderite-bearing. Locally, siderite is the predominant iron mineral in the iron-formation, but we have identified no blocks in which it is the most abundant mineral within an entire $1 / 4-\mathrm{mi}^{2}\left(0.65-\mathrm{km}^{2}\right)$ area. Thus, this large tonnage does not represent additional iron-formation over that of the first four classes, but is a repetition of the tonnage indicated for hematitic, magnetic, and silicate iron-formation that also contains siderite as an abundant ( $>10$ percent) mineral. The amount of each class that contains siderite in quantities greater than 10 percent is also shown in figure 4.

These figures indicate that the Negaunee contains a maximum of about 167 billion long tons of ironformation that might be treatable by existing concentrating processes or modifications of them. About 44 billion tons of this material is at depths of less than 1,000 feet $(304.8 \mathrm{~m})$ beneath the surface and might be accessible to open-pit mining. Certainly, some percentage of that amount will never be economically available from open pits. However, the error introduced by including economically unavailable iron-formation in this assessment is at least partly offset because we excluded iron-formation at depths greater than 1,000 feet $(304.8 \mathrm{~m})$, some of which will probably be mined at presently operating open pits. Future pits might also be deeper than 1,000 feet $(304.8 \mathrm{~m})$. We emphasize that these figures can in no way be construed to represent economically recoverable ore. They simply indicate the maximum amount of material that meets minimum requirements to be considered as potential concentrating-grade ore. Many other variables must be defined in order to make a more certain assessment of the economic potential of the material. Many of these variables are not geologic and cannot be treated by means of our data base. Of the geologic variables, many require detailed information far in 
excess of our data base and cannot be estimated. A few additional geologic variables that we can estimate are considered below.

Two important variables in determining the feasibility of open-pit mining are the amount of overlying waste rock that must be stripped and the amount of interlayered waste rock that must be moved along with ore. Figures 5 and 6 show maximum tonnages of possible treatable iron-formation within 1,000 feet $(304.8 \mathrm{~m})$ of the surface that can be mined relative to the amount of waste rock that would be moved. No generalizations can be made for the amount of waste that can be moved economically. The economics of individual mining plans are governed by a complex set of factors, and there is,

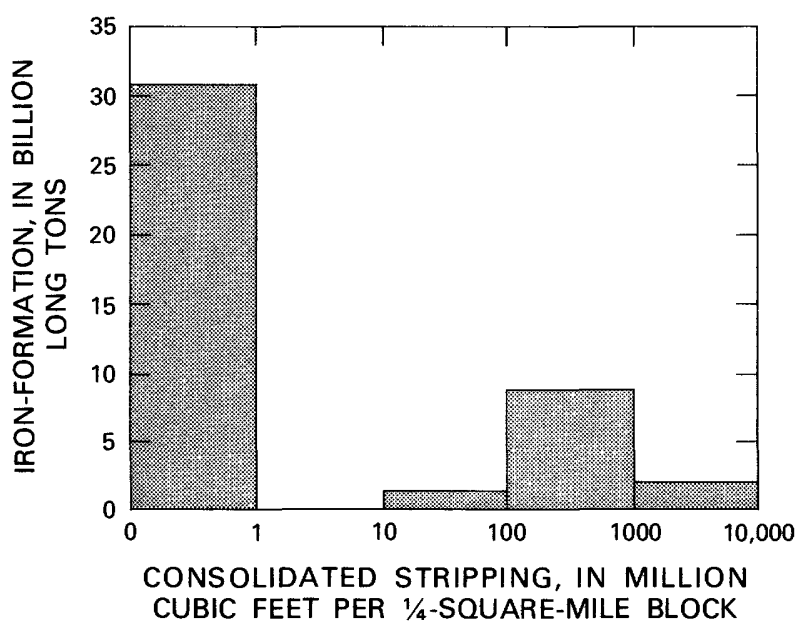

FiguRe 5.-Histogram showing billions of long tons of the possibly treatable Negaunee Iron-formation within 1,000 feet $(304.8 \mathrm{~m})$ of the surface relative to volume of consolidated waste rock overlying it. Volume of waste is calculated only within vertical boundaries of each $1 / 4-\mathrm{mi}^{2}$ block, not within inward sloping boundaries as would probably be required for development of an open pit.

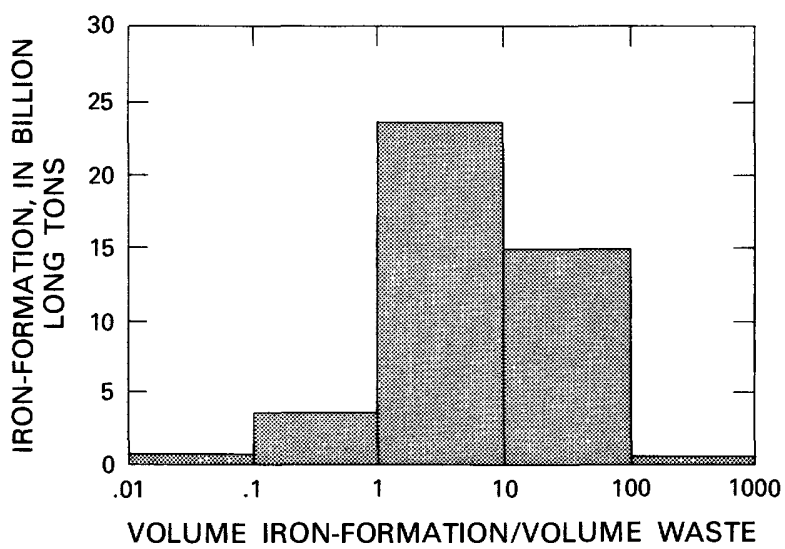

Figure 6.-Histogram showing billions of long tons of the possibly treatable Negaunee Iron-formation within 1,000 feet $(304.8 \mathrm{~m})$ of the surface with various ratios of volume of iron-formation to volume of interlayered waste rock. therefore, a wide range in tolerance for waste rock. No attempt is made in this report to estimate amounts of iron-formation that could be mined economically relative to amounts of associated waste rock that would need to be moved.

Figure 5 shows, however, that development of a major part of the resource may not be hindered seriously by large amounts of overlying waste. Nearly three-quarters of the material within 1,000 feet $(304.8 \mathrm{~m})$ of the surface requires stripping of less than 1 million $\mathrm{ft}^{3}\left(28,321 \mathrm{~m}^{3}\right)$ of consolidated material for each $1 / 4-\mathrm{mi}^{2}\left(0.65-\mathrm{km}^{2}\right)$ area to uncover the iron-formation. These figures for overlying consolidated waste must be considered approximate minima for two reasons. First, we have defined overlying stripping as being restricted mostly to quartzite and conglomerate stratigraphically above the Negaunee, whereas an individual mine may be in a stratigraphically medial position in the Negaunee and have a metadiabase sill, included in our figures as interlayered waste, as overlying rock. When individual mines are considered, therefore, there may in fact be material to be stripped, such as metadiabase, that in our figures is included as interlayered waste rather than as overlying waste. Second, in calculating volumes of stripping, we have calculated only material directly above the iron-formation of interest, which, in effect, assumes vertical pit walls if our figures are applied to an individual mine. Because vertical pits are generally not feasible in actual mining practice, overlying and adjoining waste volumes for an individual mine would often be somewhat greater than our figures indicate.

Figure 6 indicates that more than 90 percent of the 44 billion tons of possibly treatable iron-formation within 1,000 feet $(304.8 \mathrm{~m})$ of the surface has iron-formation: waste ratios greater than $1: 1$ and that nearly 16 billion tons has a ratio of better than $10: 1$. Thus, excessive volumes of interlayered waste rock do not seem a major hindrance to development of a large percentage of the resources. Much of the waste is interlayered metadiabase sills, which are generally large discrete bodies (see fig. 1). In mining, much of the sills could be left in place, effectively improving the iron-formation: waste ratios of the material actually mined. However, in places, the presence of the metadiabase sills would cause mining of some underlying iron-formation to be economically unattractive.

\section{RESOURCE CLASSIFICATION}

A classification system for resources based on degree of economic feasibility of mining and process- 
ing the ore and on degree of geologic assurance with which the deposit is known was proposed by McKelvey (1973) and has been adopted by the U.S. Geological Survey and the U.S. Bureau of Mines. A modified version of that classification is used here. Our classification differs from McKelvey's in two ways. First, we do not include categories for undiscovered resources. We consider that the Marquette district is so thoroughly explored that all the material indicated by our figures is known with adequate degree of assurance to be considered an identified resource. The possibility that substantial additional deposits of iron-formation exist in the district is negligible in light of the great amount of geologic and geophysical data on the area. Second, we do not subdivide reserves as suggested by McKelvey. We consider that the definition of economic availability of iron ore is dependent on many factors that cannot be estimated without very detailed studies and that reserves are restricted to thoroughly tested material at existing mines or in areas where development is known to be feasible in the immediate future.

In figure 7 , the tonnage that we assign to each of seven resource categories is shown. Under economic deposits, we include estimates of economically recoverable material at three existing taconite mines plus one deposit at which development in the near

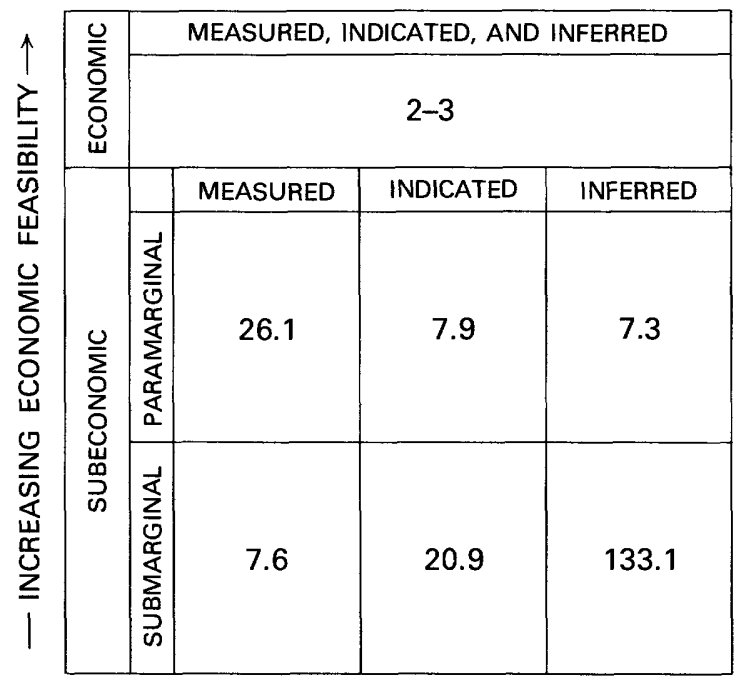

- DECREASING GEOLOGIC ASSURANCE $\rightarrow$

[All figures in billion long tons]

Figure 7.-Resource classification chart showing billions of long tons of Negaunee Iron-formation assigned to categories based on varying degrees to which material approaches the characteristics of presently economic deposits and the degree of assurance with which the deposit is known. future has been announced. These estimates are based on annual production capacity of concentrating plants and presumed minimum life span of the mines, as well as on published reserve figures.

Under subeconomic resources, we have divided material into two categories-paramarginal resources and submarginal resources-on the basis of mineralogy and depth below the surface. Paramarginal resources include material that has magnetite, hematite, or goethite as the most abundant iron mineral and that is within 1,000 feet $(304.8 \mathrm{~m})$ of the surface. Thus, paramarginal resources include material that is potentially accessible to open-pit mining, and that has mineralogical similarities to material presently being processed commercially. Although large amounts of this material may not be processible by techniques currently used, we consider it likely that new processes or modifications of current ones could successfully beneficiate much of it. All the material has one feature in commona large percentage of the contained iron is present in a mineralogic form (oxide or hydrous oxide minerals), for which beneficiation requires only the physical separation of iron minerals from gangue minerals.

Submarginal resources include material at depths greater than 1,000 feet $(304.8 \mathrm{~m})$ and all material, regardless of depth, that contains iron-silicate as the most abundant mineral. Submarginal resources, therefore, include (1) material that to become economically recoverable would require a substantial improvement in mining or processing technology or a substantial increase in price of iron concentrates, or both; and (2) material for which the concentration of much of the contained iron requires a chemical as well as a physical process.

We have rather arbitrarily defined limits on degree of geologic assurance as five or more data points (outcrops plus drillholes) per $1 / 4 \mathrm{mi}^{2}\left(0.65 \mathrm{~km}^{2}\right)$ for measured resources, and one to four data points per $1 / 4 . \mathrm{mi}^{2}\left(0.65 \mathrm{~km}^{2}\right)$ for indicated resources. Material not known directly but whose presence is predicted by projection of data for relatively short distances is considered an inferred resource.

Figure 7 shows that for paramarginal resources about 34 billion long tons, or more than 80 percent of the category, is known from at least one data point per $1 / 4 \mathrm{mi}^{2}\left(0.65 \mathrm{~km}^{2}\right)$ and more than 60 percent is known from five or more data points. This high degree of geologic assurance reflects the detailed surface mapping of the district as well as the great number of drillholes that penetrate the first 1,000 feet beneath the surface. 
For submarginal resources the situation is reversed. Only about 7.6 billion long tons, or about 5 percent of the category is known from more than five data points per $1 / 4 \mathrm{mi}^{2}\left(0.65 \mathrm{~km}^{2}\right)$, whereas greater than 80 percent or 133.1 billion long tons is inferred by projection of data. Because inferred submarginal resources account for about 65 percent of the total resource, we would like to consider briefly the degree of assurance with which the material is inferred. We are dealing with a stratigraphic unit, the Negaunee Iron-formation, that is known from surface and near-surface data to vary gradually along strike in a manner in which the most important variables such as thickness and mineralogy can generally be predicted rather well between data points 1 mile $(1.6 \mathrm{~km})$ apart. Our data bank is not constructed so as to identify readily the nearest data point to a block, but we believe, from our experience in analyzing the data, that seldom is a block more than 1 mile from a data point. Therefore, although. by projecting data we introduce some uncertainty into our figures for inferred resources, we feel, from the degree and scale of variation seen at the surface, that in projecting our data relatively short distances, we have not introduced any gross errors.

\section{ESTIMATES OF TOTAL RECOVERABLE IRON}

Ultimately the most important values for iron resources are estimates of the amount of metallic iron that can be produced from available iron-formation. As we have indicated previously, we do not attempt to define amounts of economically recoverable iron. We have, however, estimated the maximum amount of iron that might be produced from known ironformation, given economic conditions that allow its profitable mining and processing. These figures indicate the maximum geologic availability of iron under existing or somewhat improved technologic and economic conditions and can be considered an upper limit for iron reserves.

To define the amount of recoverable iron, we must answer two basic questions. First, what percentage of the iron-formation is amenable to processing to make a concentrate that meets quality standards for contained iron and silica? Second, of the amount of iron-formation that meets minimum quality standards, what percentage of the iron can be recovered?

To answer these questions requires data on the metallurgical response of iron-formation to various concentrating processes. Comprehensive tests for the Negaunee as a whole have never been made; rather, a few areas, which for a variety of reasons have received concentrated study, have been rather thoroughly tested, and we are largely without data for the remainder of the district. Precise estimates based directly on empirical measurements cannot be made, but the available metallurgical data can be used to predict the maximum amount of iron recoverable from untested material. To do this, a Monte Carlo simulation model was designed, based on the assumption that the material for which test results are known is the same as material to which the data are being projected. The results provided by the model are no more or less valid than that assumption. Possible errors of overestimation introduced by this assumption are discussed in more detail below. The empirical base for the model was derived from metallurgical tests by the U.S. Bureau of Mines (Heising and Frommer, 1967) and from data provided by mining companies. In all, more than 36,000 feet $(10,973 \mathrm{~m})$ of drill core is included in the tests; an individual test is generally on 5-20 feet (1.5-6.1 $\mathrm{m})$ of core.

Metallurgical data are available for 41 sample blocks. They are divided into three types of tests and are shown in figure 8 and table 2 . Ten sample

TABLE 2.-Metallurgical data used in simulation model [Each line represents average results for one data block]

\begin{tabular}{|c|c|c|c|c|}
\hline $\begin{array}{c}\text { Concentrate } \\
\text { Fe } \\
\text { (in wt. } \\
\text { percent) }\end{array}$ & $\begin{array}{c}\text { Concentrate } \\
\mathrm{SiO}_{2} \\
\text { (in wt. } \\
\text { percent) }\end{array}$ & $\begin{array}{c}\text { Recoverable } \\
\text { Fe } \\
\text { (in wt. } \\
\text { percent) }\end{array}$ & $\begin{array}{c}\text { Iron- } \\
\text { formation } \\
\text { in block } \\
\text { (million } \\
\text { long tons) }\end{array}$ & $\begin{array}{l}\text { Length of } \\
\text { drill core } \\
\text { tested (feet) }\end{array}$ \\
\hline \multicolumn{5}{|c|}{ Magnetic separation } \\
\hline $\begin{array}{l}60.8 \\
67.2 \\
63.4 \\
63.5 \\
66.0 \\
64.7 \\
57.2 \\
55.6 \\
64.1 \\
63.5 \\
60.6 \\
65.7 \\
62.7 \\
66.5 \\
67.1 \\
55.7 \\
58.0 \\
55.9 \\
57.6\end{array}$ & $\begin{array}{r}12.8 \\
5.9 \\
10.7 \\
9.4 \\
9.8 \\
8.8 \\
17.6 \\
19.1 \\
9.1 \\
9.3 \\
3.8 \\
6.4 \\
8.0 \\
7.2 \\
7.2 \\
20.3 \\
15.7 \\
22.4 \\
16.3\end{array}$ & $\begin{array}{l}38.2 \\
25.2 \\
24.7 \\
21.0 \\
28.6 \\
25.8 \\
34.2 \\
31.1 \\
17.3 \\
25.7 \\
27.0 \\
27.2 \\
49.5 \\
19.0 \\
43.8 \\
29.4 \\
50.2 \\
44.2 \\
48.2\end{array}$ & $\begin{array}{r}296.9 \\
179.9 \\
249.3 \\
142.9 \\
332.9 \\
309.3 \\
69.2 \\
84.7 \\
24.9 \\
52.3 \\
52.4 \\
39.2 \\
13.3 \\
28.8 \\
8.9 \\
47.0 \\
39.2 \\
27.4 \\
9.6\end{array}$ & $\begin{array}{r}3,320 \\
153 \\
4,842 \\
1,241 \\
1,521 \\
1,706 \\
697 \\
2,388 \\
234 \\
911 \\
5 \\
5 \\
15 \\
10 \\
10 \\
5 \\
60 \\
467 \\
137\end{array}$ \\
\hline \multicolumn{5}{|c|}{ Selective flocculation } \\
\hline $\begin{array}{l}60.2 \\
66.3 \\
64.1 \\
66.4 \\
66.7 \\
51.1 \\
61.5 \\
57.5 \\
60.5 \\
62.3\end{array}$ & $\begin{array}{r}18.4 \\
4.0 \\
5.8 \\
5.3 \\
4.4 \\
19.0 \\
11.8 \\
16.0 \\
13.1 \\
10.5\end{array}$ & $\begin{array}{l}36.0 \\
20.6 \\
29.6 \\
28.7 \\
25.5 \\
18.7 \\
33.9 \\
30.1 \\
33.7 \\
34.8\end{array}$ & $\begin{array}{r}127.4 \\
345.8 \\
145.8 \\
153.8 \\
205.9 \\
142.2 \\
204.5 \\
182.8 \\
287.3 \\
75.9\end{array}$ & $\begin{array}{c}715 \\
\text { Trench samples } \\
\text { Do. } \\
\text { Do. } \\
\text { Do. } \\
\text { Do. } \\
\text { 3,974 } \\
654 \\
3,929 \\
7,948\end{array}$ \\
\hline \multicolumn{5}{|c|}{ Froth flotation } \\
\hline $\begin{array}{l}64.9 \\
63.0 \\
64.1 \\
59.5 \\
67.9 \\
67.0 \\
66.8 \\
65.5 \\
58.8 \\
52.2 \\
65.5 \\
61.7\end{array}$ & $\begin{array}{r}4.0 \\
8.1 \\
4.3 \\
6.8 \\
3.1 \\
2.1 \\
4.0 \\
5.8 \\
13.4 \\
9.3 \\
8.2 \\
8.8\end{array}$ & $\begin{array}{l}24.7 \\
27.8 \\
38.7 \\
30.2 \\
39.3 \\
35.5 \\
36.4 \\
41.7 \\
37.0 \\
23.9 \\
19.8 \\
25.2\end{array}$ & $\begin{array}{r}12.4 \\
20.6 \\
19.3 \\
15.5 \\
28.8 \\
33.1 \\
27.4 \\
8.4 \\
39.2 \\
27.4 \\
135.7 \\
79.0\end{array}$ & $\begin{array}{r}172 \\
10 \\
5 \\
5 \\
10 \\
30 \\
5 \\
10 \\
207 \\
? \\
294 \\
335\end{array}$ \\
\hline
\end{tabular}




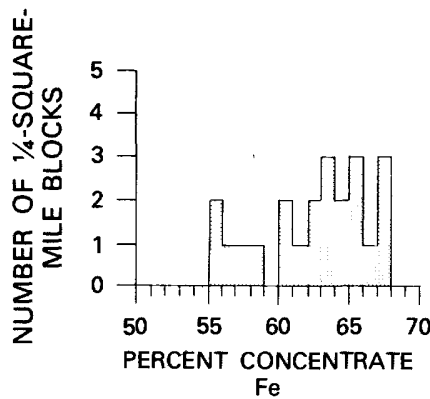

$\mathrm{Fe}$

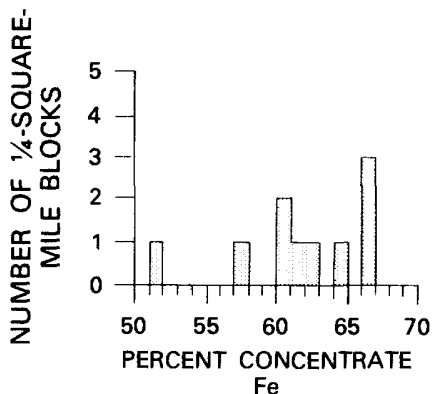

$\mathrm{Fe}$

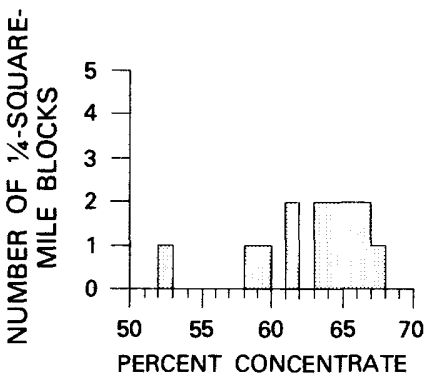

$\mathrm{Fe}$
DAVIS MAGNETIC TUBE TESTS

[Average results for each $1 / 4$-square-mile block]

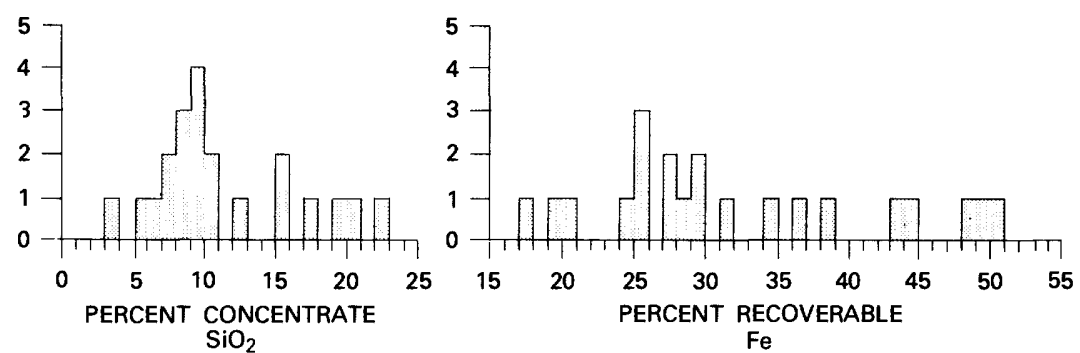

SELECTIVE FLOCCULATION TESTS

[Average results for each $1 / 4$-square-mile block]

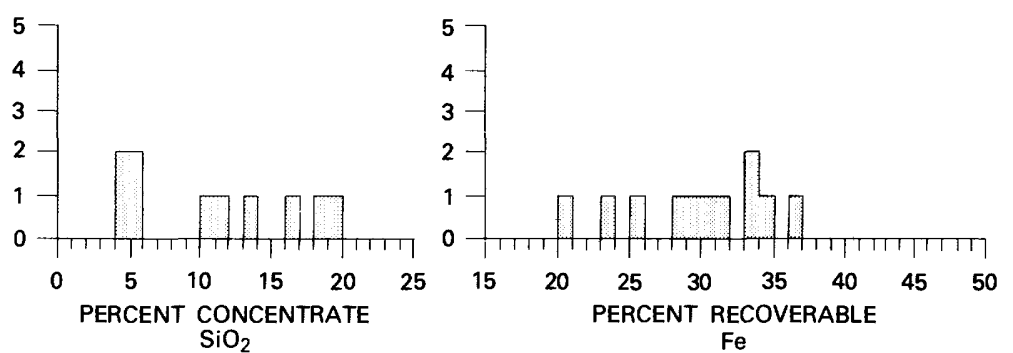

FROTH FLOTATION TESTS

[Average results for each $1 / 4$-square-mile block]

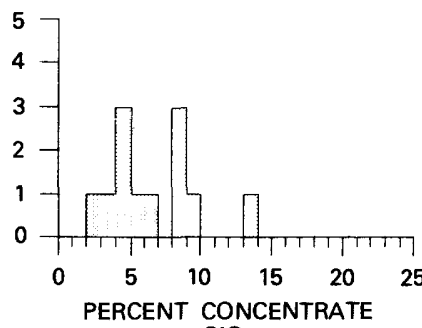

$\mathrm{SiO}_{2}$

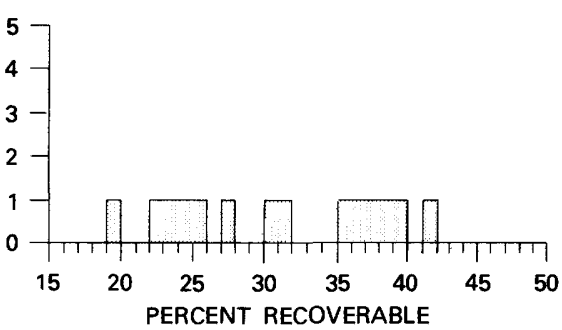

COMBINED FROTH FLOTATION, DAVIS TUBE, AND SELECTIVE FLOCCULATION TESTS

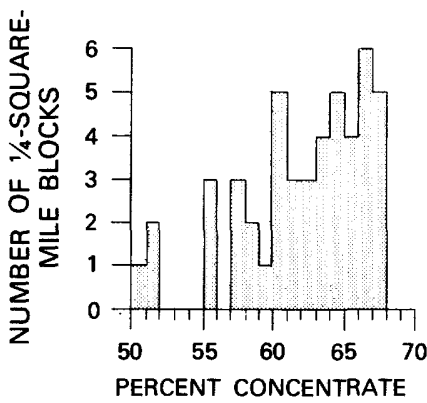

$\mathrm{Fe}$
[Average results for each $1 / 4$-square-mile block]
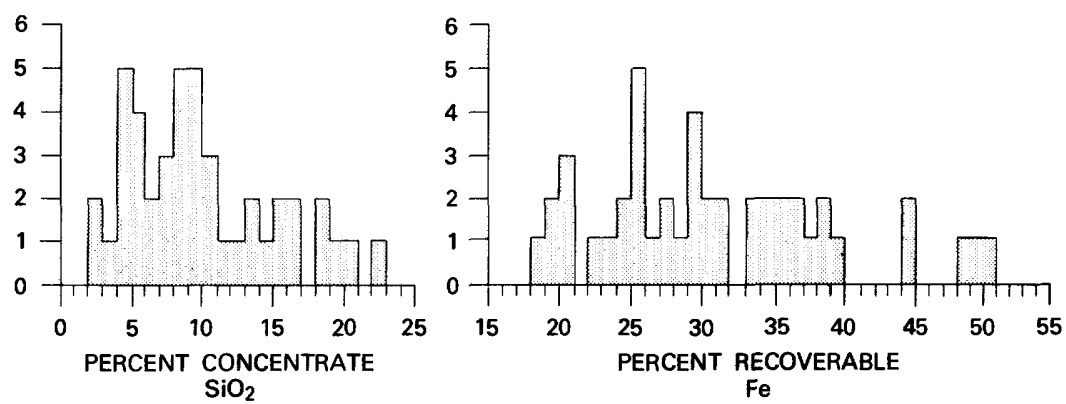

Figure 8.-Histograms showing results of three types of metallurgical tests. See table 2 for tabulated results. "Percent concentrate $\mathrm{Fe}$ " is percentage by weight of $\mathrm{Fe}$ in final concentrate; "percent concentrate $\mathrm{SiO}_{2}$ " is percentage by weight of $\mathrm{SiO}_{2}$ in final concentrate; "percent recoverable $\mathrm{Fe}$ " is percentage of crude ore recovered as Fe in final concentrate (weight $\mathrm{Fe}$ in concentrate/weight crude ore). 
blocks represent fine-grained hematitic iron-formation, 19 blocks represent magnetic iron-formation, and 12 blocks represent coarse-grained hematitic iron-formation. Each value on the histograms and in the table represents an average for one of our blocks. Each average is derived from one to more than 100 individual tests.

The model is designed to test only paramarginal resources, because metallurgical data are available only for material in which oxides and hydroxides are the most abundant iron minerals and that can be concentrated by means of current technology. Thus, large quantities of iron contained in silicate and carbonate minerals are automatically excluded because no technology exists to concentrate iron contained in these minerals. Also, iron contained in iron-formation at greater than 1,000-foot (304.8-m) depths is excluded because we have limited our estimates to material within 1,000 feet $(304.8 \mathrm{~m})$ of the surface. Paramarginal resources were divided into three categories according to mineralogy and grain size for testing against the most appropriate metallurgical data. Fine-grained hematitic and goethitic iron-formation was tested against data for selective flocculation tests. Coarse-grained hematitic iron-formation was tested against froth-flotation data, and magnetitic iron-formation was tested against Davis magnetic tube data. The distribution of these three types of iron-formation in the Marquette district is shown in figure 9.

When the simulation experiment was performed, the quality criteria used for an acceptable concentrate were iron in excess of 60 percent and silica less than 10 percent. These values are a few percentage points short of currently acceptable standards, but were chosen for two reasons. First, metallurgical tests are likely to yield results a few percentage points poorer than results that can be achieved through a concentrating process appropriately adjusted and "fine-tuned" to a particular ore body. Second, if a cutoff closer to present standards were used-for instance, 65 percent iron and 6-8 percent silica-the calculated values would exclude much, material that we feel should be included as a paramarginal resource. The data in table 2 , for example, indicate that only about one quarter of the material tested meets current standards. Yet material that fails to meet those standards by only 5 percent or less requires only a slight improvement in processing. Even though those improvements may be technically difficult to make, we believe that a high potential for such improvements exists and that material meeting our cutoff criteria is clearly a paramarginal resource.

We used the Monte Carlo simulation, a computerized statistical sampling procedure, to test each block repeatedly against known laboratory tests. In our model, the sampling began by selecting an individual block from the array of blocks containing paramarginal resources. A value for concentrate-iron percentage was chosen at random from an empirical cumulative distribution curve derived from the concentrate-iron data in table 2 . The random selections were performed in a manner whereby the results of a large number of selections, if plotted as a cumulative frequency diagram, would approximate the shape of the empirical cumulative distribution. If the concentrate-iron percentage value chosen for the first block was less than 60 percent (not acceptable quality), 0.0 tons of recoverable iron was assigned to that block. The sampling procedure continued by again selecting at random a value for concentrate iron for a second block. If the selected value this time was greater than 60 percent concentrate iron (acceptable quality), the percentage of concentrate silica was tested. Figure 10 shows that concentrate iron and concentrate silica are not independent variables; rather, as expected, a strong negative correlation exists between the two because iron and silica are the only important constituents of the rock. Thus, concentrate-silica percentage cannot be sampled from the empirical distribution as an independent variable. It was derived instead from the regression relationship: $\mathrm{SiO}_{2}=\mathrm{A}_{0}+\mathrm{A}_{1}$ (conc. $\mathrm{Fe}$ ) $\pm \sigma \mathrm{SiO}_{2}$, where $\sigma \mathrm{SiO}_{2}$ is the estimate of standard deviation of the dependent variable $\left(\mathrm{SiO}_{2}\right)$, and where $\mathrm{A}_{0}$, the intercept, and $A_{1}$, the slope coefficient, were determined by least-squares regression from the data shown in table 2 . The value for concentrate iron (conc. $\mathrm{Fe}$ ) is the value previously selected from the concentrate-iron cumulative curve. If the concentrate-silica percentage was greater than 10 percent (not acceptable quality), 0.0 tons of recoverable iron was again assigned to the block, and the sampling procedure was restarted with a third block. For blocks in which quality standards for both iron and silica were met, a value for percentage recoverable iron was selected at random from the empirical cumulative distribution for recoverable iron. The product of tons of iron-formation in the block and the randomly chosen value for percent recoverable iron is tons of recoverable iron in the block. Each block in the array was tested in this manner to yield a single evaluation, which was then repeated $100-200$ times to give an approximation of the expected re- 


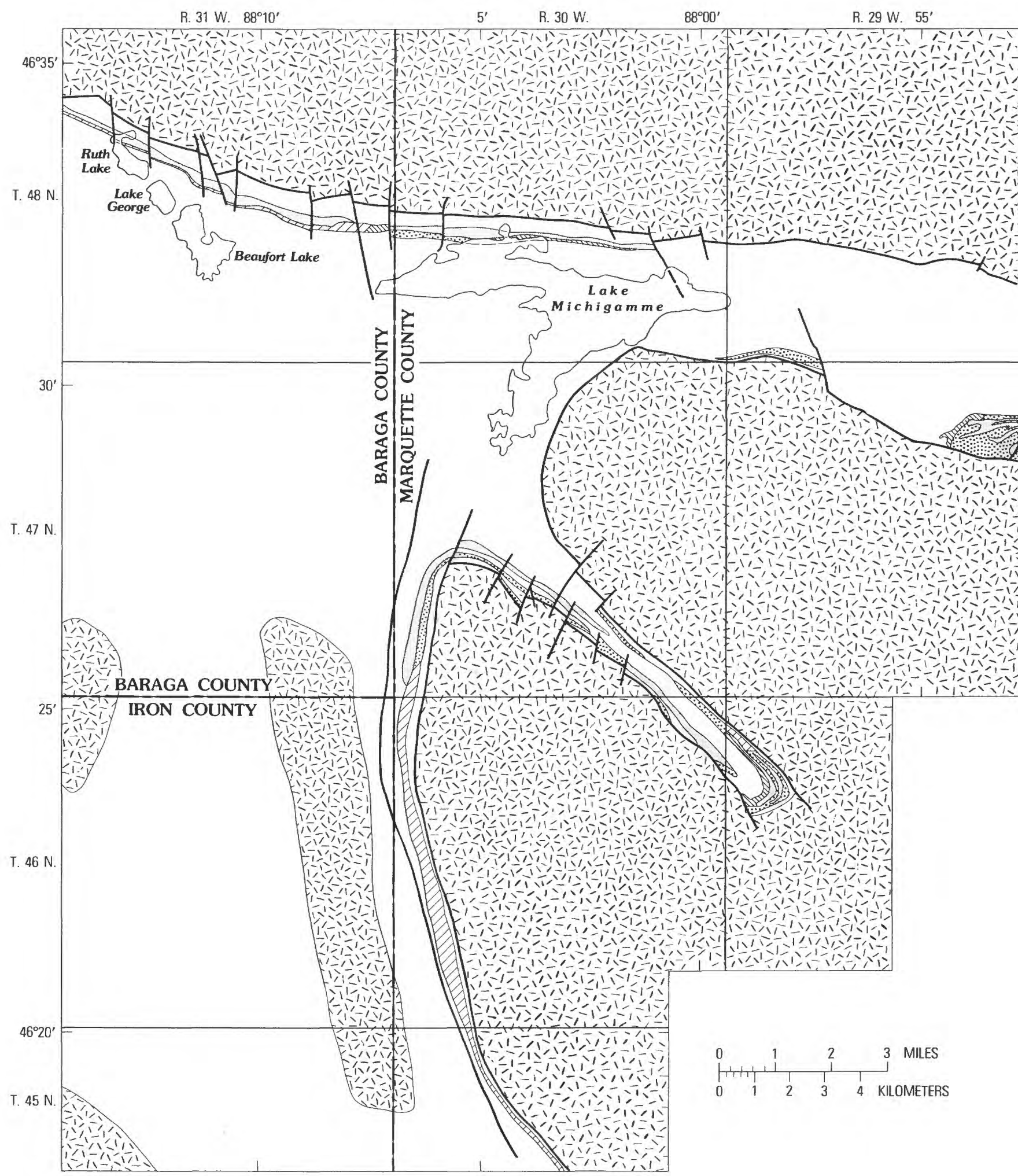

Base modified from the Cleveland Cliffs Iron Company, 1950 

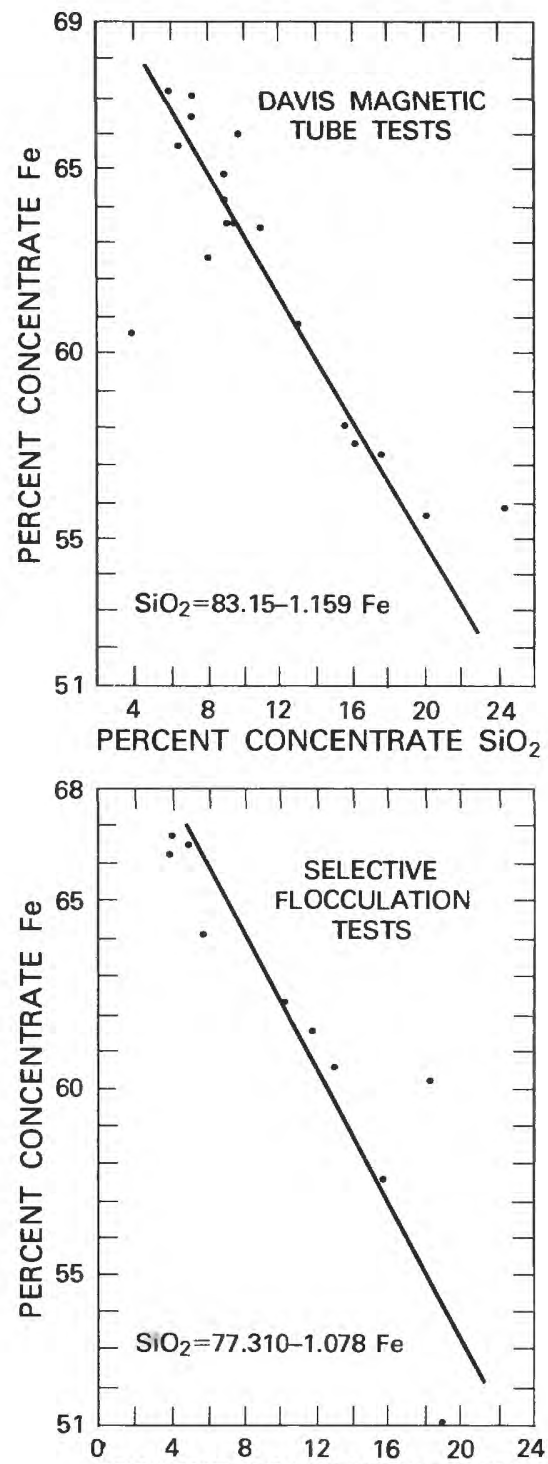

PERCENT CONCENTRATE $\mathrm{SiO}_{2}$

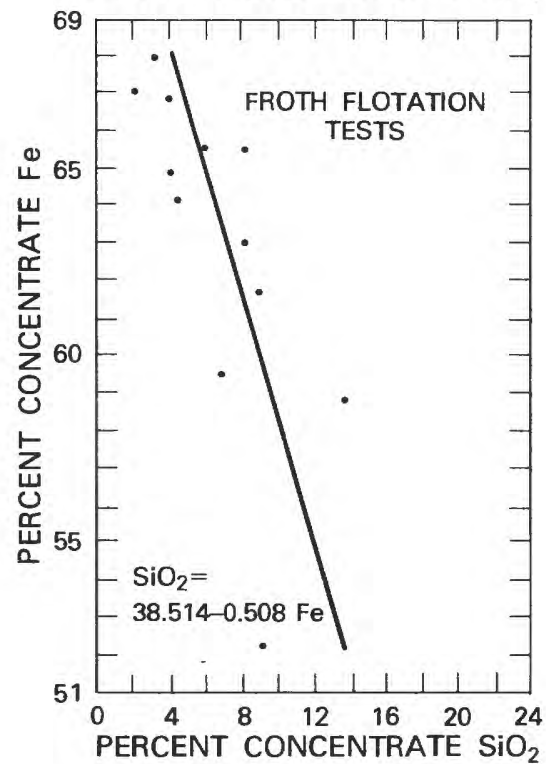

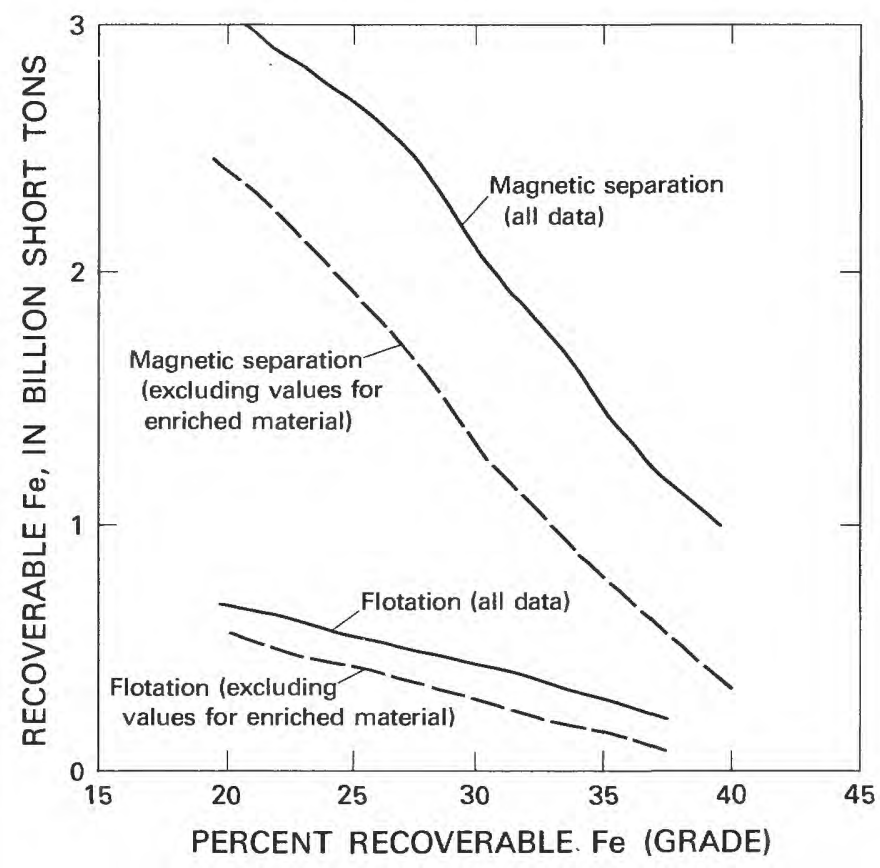

FIGURE 11.-Curves showing maximum short tons of iron potentially available within 1,000 feet $(304.8 \mathrm{~m})$ of the surface for two metallurgical classes of iron-formation at various cutoff grades. Estimates are from Monte Carlo simulation model based on the data in figures 8 and 10 .

means of our data, much of the fine-grained hematitic and goethitic iron-formation may respond more poorly than tested material. By using available data we can conclude only that when present techniques or modifications of them or yet-to-be-developed physical-separation techniques are used, a maximum of about 7 billion short tons of iron could be recovered from fine-grained hematitic and goethitic iron-formation.

Figure 11 shows that at recoverable grades down to about 20 percent iron, a maximum of about 3 billion short tons of iron could be separated from magnetic taconite and about 0.7 billion short tons, from coarse-grained hematitic iron-formation. These figures are probably too high because of the inclusion of tests yielding very high recoverable iron grades (see fig. 8), tests that were apparently made on samples of secondarily enriched iron-formation. Although such material is present in and around bodies of high-grade ore, now largely mined out, these high

Figure 10.-Regression lines showing the negative correlation between concentrate-iron percentage and concentrate-silica percentage for three types of metallurgical tests. The equations define the least-squares regression line for the data points shown. Each point represents average results for one data block. See table 2 for tabulated results. 
values have affected the distribution disproportionately to the abundance of enriched material, so that in our judgement, the figures produced from the model are perhaps 20 percent too large because of this factor alone. The dashed curves in figure 11 show the approximately adjusted values, which largely exclude the effect of the high-yield samples.

Because tests performed by mining companies are generally on material judged beforehand to be best suited for beneficiation, the test results available to us are likely to be somewhat better than those that would be obtained on currently untested materials; this factor also contributes to overestimation through the model. The discrepancy between our estimated maximum values and true values is, of course, indeterminate by any means short of comprehensive metallurgical testing.

We conclude from the above facts that if continued research can produce modest improvements in physical beneficiating techniques, a maximum of about 11 billion short tons of iron is geologically available in the Marquette district if open-pit mining to an average depth of 1,000 feet $(304.8 \mathrm{~m})$ is feasible. Several uncertainties in our data result in overestimation by an unknown factor. We conclude, however, that the true geologic availability of iron, including material for which improved processing is necessary, is 5 billion to 10 billion short tons. The percentage of that amount that will ever be economically available can only be assessed through a more detailed evaluation of local geologic data, as well as an evaluation of many other technologic, economic, political, and environmental factors. Our purpose is not to make such evaluations here, but we would like briefly to discuss some of the more important factors detrimental to the full utilization of the resource.

First among these factors is the preemption of land for uses other than mining. A very large percentage of the resource is in the exposed keel of the Marquette trough, which is also the most heavily urbanized area of the district. Ishpeming and $\mathrm{Ne}-$ gaunee, the principal population centers, are situated largely on the Negaunee Iron-formation. The economic, geographic, and cultural problems of relocating those towns are likely to prohibit open-pit mining in at least part of the area.

Many other environmental and cultural factors are involved as well, including what may be largely value judgements concerning disruption of recreational and scenic areas, alteration of drainage systems, and problems of tailings disposal. Water supply is also an important consideration. The Mar- quette district is astride the Michigan-Superior drainage divide, and the lack of large streams poses a problem of supplying process water to plants from the already heavily utilized surficial drainage systems.

These and other features together mitigate against full utilization of the iron resources of the Marquette district and suggest that only a fraction of the 5 billion to 10 billion short tons of geologically available iron will ever reach the market.

\section{FUTURE OF TACONITE MINING IN THE MARQUETTE DISTRICT}

Three taconite operations, the Republic, Empire, and Tilden mines, are now in operation in the Marquette district (see fig. 1), and a fourth, the Cascade, is likely to be opened by the mid-1980's. Expected production in 1976 is about 12 million long tons of iron-ore pellets. Figure 12 shows the projected production trends for the district on the basis of annual mill capacity at existing mines, announced mine developments and expansions, and estimated longevity of individual operations. The longevity is estimated by comparing reserves to expected production capacity. Production should reach about 19 million long tons per year by the mid-1980's if all plans for

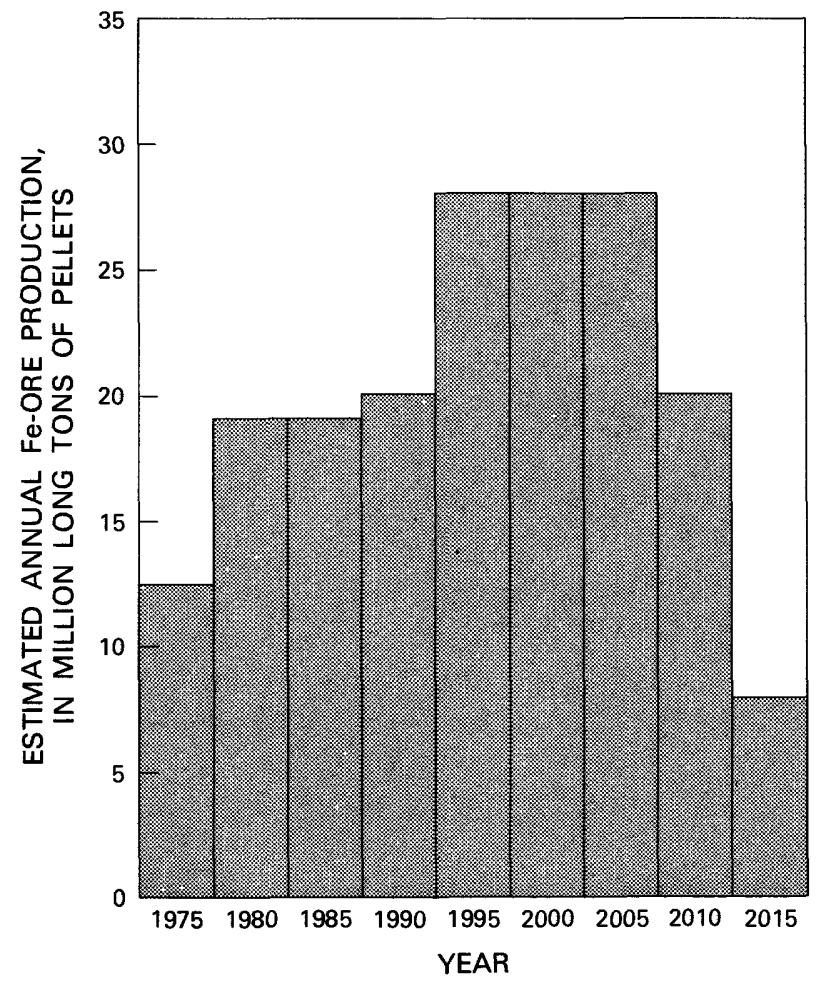

Figure 12.-Graph showing projected production trends for the Marquette district from operating mines and announced expansion and development plans. 
development and expansion are realized. Although the Republic ore body may be mined out about 1990 , that drop in production will be more than offset by the opening of the Cascade deposit and possible expansion of the Tilden mine. Thereafter production in the district should remain steady until sometime after the turn of the century when the large deposits at the Tilden, Empire, and (future) Cascade mines may be nearing exhaustion. All presently proven ore may be mined out by 2020 . This is not to say that additional reserves cannot be proven at existing mines to prolong their production span.

Although the known reserves seem adequate to maintain a high level of production in the district for many years, continued research and exploration are needed to identify additional reserves in the near future to ensure continued production at present or increased levels. Long lead times are required simply to prove the existence of and to develop a new ore body. At present, 10-15 years may be required. As more problematical areas are explored and if additional environmental and political restraints are imposed, that lead time is likely to grow. If new technology is needed to mine new deposits, the problem is compounded. More than 40 years of research and development preceded the first magnetic taconite plant, and about 20 years were required to deveop the concentrating process recently used for the first time at the Tilden mine.

In view of these long lead times, we believe that ore reserves of 30 years are only slightly more than adequate to ensure continued mining and should not be viewed as a reason for complacency about the long-term future of the district.

\section{EFFECT OF TECHNOLOGIC ADVANCES ON IRON RESOURCES}

The economic availability of iron from taconite is largely a function of the technology for mining and processing. In the past 20 years, great strides have been made in that technology. Most of the present reserves were not feasible to mine and process 20 years ago, and fine-grained hematitic taconite, which forms a major percentage of both reserves and paramarginal resources, has been processed commercially only since early 1975 . Further technologic advances will almost undoubtedly improve the resource base of the Marquette Range, and we conclude this report with a qualitative appraisal of the effect of improved technology on iron resources.

The area in which technologic improvement seems most likely and in which it would be most beneficial is mining techniques that would make possible both underground mines and deeper open-pit mines. At best, only about 20 percent of taconite that might be processible by current methods is now accessible to mining, so that improving the ability to mine deeper could easily increase the paramarginal resources by a factor of two or more.

Also, continued metallurgical testing would define more certainly the amount and location of iron-formation actually amenable to beneficiation by current techniques; it would also define what improvements or new techniques are needed. Such research, traditionally conducted by mining companies and the U.S. Bureau of Mines, could add greatly to the amount of geologically available iron.

Other fields in which new developments might take place are in processing of iron-silicate ironformation or sideritic iron-formation. Figure 4 shows that a great tonnage of taconite contains greater than 10 percent siderite. Much of this taconite is already included as a paramarginal resource because it also contains abundant magnetite or hematite. At present, siderite is a gangue mineral because the iron contained in it is not recoverable; the presence of siderite lowers the recoverable grade. The development of a process to recover the iron in siderite would increase the total recoverable iron in the district and would render presently uneconomic parts of the magnetic and hematitic taconite more economically attractive. Although high-grade siderite ore is presently mined, roasted, and sintered at a commercial scale in other districts, it has not been mined commercially from taconite. Because of the great amount of energy needed for such a process, its development seems unlikely in the energy-short economy of the near future.

\section{CONCLUSIONS}

The Negaunee Iron-formation in the Marquette district of Michigan contains about 205 billion long tons of material averaging about 32 percent iron. About 49 billion long tons is within 1,000 feet ( 304.8 $m)$ of the surface.

Considering only material that might be minable from open pits and that has suitable mineralogy and grain size to be potentially processible by current concentrating processes or by modifications of them, a maximum of about 11 billion short tons of iron is potentially recoverable from the district. However, many geologic, economic, technologic, political, and environmental restraints are likely to prevent utilization of much of it.

Even though presently proven reserves are adequate to ensure production of more than 20 million 
long tons of iron pellets per year for 30-40 years, long lead times in developing new deposits and new processing techniques require exploration and research in the near future to ensure continued production beyond the next 30 years, or increased production within the next 30 years.

\section{REFERENCES CITED}

Bowen, R. W., and Botbol, J. M., 1975, The geologic retrieval and synopsis program (GRASP): U.S. Geol. Survey Prof. Paper 966, $87 \mathrm{p}$.

Cannon, W. F., 1974, Bedrock geologic map of the Greenwood quadrangle, Marquette County, Michigan: U.S. Geol. Survey Geol. Quad. Map GQ-1168.

- 1975, Bedrock geologic map of the Republic quadrangle, Marquette County, Michigan: U.S. Geol. Survey Misc. Inv. Map I-862.

Cannon, W. F., and Klasner, J. S., 1974, Preliminary geologic map of the Witch Lake 15-minute quadrangle, Michigan: U.S. Geol. Survey open-file report, 7 p., 1 pl., scale $1: 62,500$.

1975a, Preliminary geologic map of the southern part of the Diorite 71/2-minute quadrangle, Marquette County, Michigan: U.S. Geol. Survey open-file report 75-11, 7 p., 1 pl., scale $1: 24,000$.

$1975 \mathrm{~b}$, Preliminary geologic map of the southern part of the Champion 71/2-minute quadrangle, Marquette County, Michigan: U.S. Geol. Survey open-file report 75-10, 8 p., 1 pl., scale $1: 24,000$.

Clark, L. D., Cannon, W. F., and Klasner, J. S., 1975, Bedrock geologic map of the Negaunee $\mathrm{SW}$ quadrangle, Marquette County, Michigan: U.S. Geol. Survey Quad. Map GQ-1226.
Gair, J. E., 1975, Bedrock geology and ore deposits of the Palmer quadrangle, Marquette County, Michigan: U.S. Geol. Survey Prof. Paper 769, 159 p.

Heising, L. F., and Frommer, D. W., 1967, Lake Superior iron resources-Preliminary samples and metallurgical evaluation of selected Michigan-Wisconsin iron formations: U.S. Bur. Mines Rept. Inv. 6895, $31 \mathrm{p}$.

James, H. L., 1954, Sedimentary facies of iron-formation: Econ. Geology, v. 49, no. 3, p. 235-293.

- 1955, Zones of regional metamorphism in the Precambrian of northern Michigan: Geol. Soc. America Bull., v. 66 , no. 12 , p. 1455-1487.

Klasner, J. S., and Cannon, W. F., 1974, Geologic interpretation of gravity profiles in the western Marquette district, northern Michigan: Geol. Soc. America Bull., v. 85, no. 2, p. 213-218. 1975a, Preliminary geologic map of the southern part of the Michigamme $7 \frac{1 / 2}{\text {-minute quadrangle, Marquette }}$ and Baraga Counties, Michigan: U.S. Geol. Survey open-file report $75-9,8$ p., 1 pl., scale $1: 24,000$.

1975b, Preliminary geologic map of the southern part of the Three Lakes 71/2-minute quadrangle, Baraga County, Michigan: U.S. Geol. Survey open-file report 75-8, 7 p., 1 pl., scale $1: 24,000$.

McKelvey, V. E., 1973, Mineral resource estimates and public policy in Brobst, D. A., and Pratt, W. P., eds., United States mineral resources: U.S. Geol. Survey Prof. Paper 820, p. 9-19.

Puffett, W. P., 1974, Geology of the Negaunee quadrangle, Marquette County, Michigan: U.S. Geol. Survey Prof. Paper 788, 53 p.

Simmons, G. C., 1974, Bedrock geologic map of the Ishpeming quadrangle, Marquette County, Michigan: U.S. Geol. Survey Geol. Quad. Map GQ-1130. 


